\title{
The endoplasmic reticulum-plasma membrane tethering protein TMEM24 is a regulator of cellular $\mathrm{Ca}^{2+}$ homeostasis
}

\author{
Beichen Xie ${ }^{1}$, Styliani Panagiotou ${ }^{1}$, Jing Cen $^{1}$, Patrick Gilon ${ }^{2}$, Peter Bergsten ${ }^{1}$ and Olof Idevall- \\ Hagren $^{1 *}$
}

1. Department of Medical Cell Biology, Uppsala University, BMC Box 571, 75123 Uppsala, Sweden. 2. Pole of Endocrinology, Diabetes and Nutrition (EDIN), Institute of Experimental and Clinical Research (IREC), Université Catholique de Louvain

* Corresponding author, olof.idevall@mcb.uu.se, +46184714428

Key words: $\mathrm{MCS}, \mathrm{Ca}^{2+}$, insulin secretion, phosphoinositides, mitochondria

Word count: 10771 (including references)

Number of Figures: 4

Number of supplementary figures: 1

Endoplasmic reticulum (ER) - plasma membrane (PM) contacts are sites of lipid exchange and $\mathrm{Ca}^{2+}$ transport, and both lipid transport proteins and $\mathrm{Ca}^{2+}$ channels specifically accumulate at these locations. In pancreatic $\beta$-cells, both lipid- and $\mathrm{Ca}^{2+}$ signaling are essential for insulin secretion. The recently characterized lipid transfer protein TMEM24 dynamically localize to ER-PM contact sites and provide phosphatidylinositol, a precursor of $\mathrm{PI}(4) \mathrm{P}$ and $\mathrm{PI}(4,5) \mathrm{P}_{2}$, to the plasma membrane. $\beta$ cells lacking TMEM24 exhibit markedly suppressed glucose-induced $\mathrm{Ca}^{2+}$ oscillations and insulin secretion but the underlying mechanism is not known. We now show that TMEM24 only weakly interact with the PM, and dissociates in response to both diacylglycerol and nanomolar elevations of cytosolic $\mathrm{Ca}^{2+}$. Release of TMEM24 into the bulk ER membrane also enables direct interactions with mitochondria, and we report that loss of TMEM24 results in excessive accumulation of $\mathrm{Ca}^{2+}$ in both the ER and mitochondria and in impaired mitochondria function.

\section{INTRODUCTION}

Lipid exchange between the endoplasmic reticulum (ER) and the plasma membrane (PM) is facilitated by lipid-transport proteins that are concentrated to, and participate in the formation of, ER-PM contact sites. These junctions are also important sites for cellular $\mathrm{Ca}^{2+}$ homeostasis, and the lipid transport is often coupled to changes in the cytosolic $\mathrm{Ca}^{2+}$ concentration (Balla, 2018; Chung et al., 2017; Saheki $\&$ De Camilli, 2017). The changes in membrane lipid concentrations occurring as a consequence of lipid transport may also influence $\mathrm{Ca}^{2+}$ influx or extrusion through modulation of $\mathrm{Ca}^{2+}$ channel activity or clustering (Johnson et al., 2018; Suh et al., 2010; Sun et al., 2019; Xie et al., 2016). TMEM24 is a recently characterized lipid transport protein that localize to ER-PM contacts where it, through an Nterminal synaptotagmin-like mitochondrial-lipid-binding (SMP) domain, provides the plasma membrane with phosphatidylinositol, the precursor of the signaling lipids $\mathrm{PI}(4) \mathrm{P}$ and $\mathrm{PI}(4,5) \mathrm{P}_{2}$ (Lees et al., 2017; Sun et al., 2019). It binds negatively charged lipids in the plasma membrane via a Cterminal polybasic region, and neutralization of positively charged amino acids in this region by PKCdependent phosphorylation results in TMEM24 dissociation from the plasma membrane. TMEM24 is also equipped with a C2-domain, which, however, seems dispensable for both plasma membrane binding and lipid transport. The spatial regulation of TMEM24 activity differs from other SMP- and C2-domain proteins, such as the Extended synaptotagmins, whose interaction with the plasma membrane and lipid transport are instead triggered by $\mathrm{Ca}^{2+}$ elevation (Bian et al., 2018; Giordano et al., 2013; Idevall-Hagren et al., 2015). 
Pancreatic beta-cells are secretory cells that produce insulin and release this hormone to the circulation in response to elevated blood glucose levels. The mechanism controlling insulin secretion is wellcharacterized and involves glucose uptake and metabolism, resulting in an elevated ATP/ADP ratio which in turn closes ATP-sensitive $\mathrm{K}^{+}\left(\mathrm{K}_{\mathrm{ATP}}\right)$-channels, causing membrane depolarization, opening of voltage-dependent $\mathrm{Ca}^{2+}$ channels, $\mathrm{Ca}^{2+}$ influx and the fusion of insulin-containing granules with the plasma membrane (Rorsman \& Ashcroft, 2018). $\mathrm{Ca}^{2+}$ is the most important trigger of insulin secretion, but the response can also be modulated by many factors, including lipids and lipid-derived signaling molecules. Phosphoinositides in particular has been shown to regulate insulin secretion at several stages, including membrane depolarization, $\mathrm{Ca}^{2+}$ influx and granule docking and release (Wuttke, 2015). The phosphoinositide $\mathrm{PI}(4,5) \mathrm{P}_{2}$ also serves as a precursor of inositol 1,4,5-trisphosphate (IP3), which triggers $\mathrm{Ca}^{2+}$ release from the ER and may contribute to insulin granule exocytosis, and diacylglycerol (DAG), which together with $\mathrm{Ca}^{2+}$ amplifies secretion by stimulating the protein kinase C activity (Wuttke et al., 2013, 2016). Lipid transport at ER-PM contact sites are important for the normal function of insulin-secreting $\beta$-cells. DAG transport by E-Syt1 was recently found to provide negative feedback on insulin secretion after being recruited to sites of $\mathrm{Ca}^{2+}$ influx where it locally clears the plasma membrane of the pro-secretory lipid (Xie et al., 2019). $\beta$-cells with reduced E-Syt1 expression thus exhibits increased accumulation of plasma membrane DAG and excess insulin secretion in response to glucose. E-Syt1 occupies the same contact sites as TMEM24. However, their presence at these contacts does not overlap in time due to their inverse dependence of plasma membrane binding on the prevailing $\mathrm{Ca}^{2+}$ concentration (Xie et al., 2019). Interestingly, TMEM24 was recently found to be indispensable for glucose-stimulated insulin secretion (Lees et al., 2017; Pottekat et al., 2013). The complete loss of insulin secretion in clonal TMEM 24 knockout $\beta$-cells is likely caused by an effect on $\beta$-cell $\mathrm{Ca}^{2+}$ homeostasis. $\beta$-cells lacking TMEM24 thus exhibit markedly suppressed glucose-induced $\mathrm{Ca}^{2+}$ oscillations, but the mechanism behind this is not clear (Lees et al., 2017). One possibility is that TMEM 24 is necessary for maintaining plasma membrane $\mathrm{PI}(4,5) \mathrm{P}_{2}$ required for ion channel gating during stimulation, although the global $\mathrm{PI}(4,5) \mathrm{P}_{2}$ levels are unaltered in TMEM24 KO cells (Lees et al., 2017). The dynamics of TMEM24 in glucose-stimulated $\beta$-cells is also difficult to reconcile with a role as a positive regulator of insulin secretion, since it is spatially separated from this process during glucose stimulation. Clarification of the role of TMEM24 in the regulation of insulin secretion is therefore required.

We now show that the subcellular distribution of TMEM24 is highly dynamic and influenced by both $\mathrm{Ca}^{2+}$ and plasma membrane DAG. In contrast to previous studies, we do not find a requirement of TMEM24 for normal $\mathrm{Ca}^{2+}$-triggered insulin secretion. Instead, we identified TMEM24 as an important regulator of intracellular $\mathrm{Ca}^{2+}$ stores, and show that $\beta$-cells lacking TMEM24 exhibit both ER and mitochondrial $\mathrm{Ca}^{2+}$ overloading, resulting in dissipation of the mitochondrial membrane potential and in impaired oxidative phosphorylation.

\section{MATERIALS AND METHODS}

\section{Plasmids and Reagents}

TMEM24-EGFP (Lees et al., 2017), E-Syt1-GFP (Giordano et al., 2013) and mRFP-PH-PLC $\delta 1$ were gifts from Pietro De Camilli (Yale University). VAMP2-pHluorin and NPY-mCherry were gifts from Sebastian Barg (Uppsala University). GFP-P4M-SidM was a gift from Gerald Hammond (University of Pittsburgh, Addgene plasmid 51472)(Hammond et al., 2014). GFP-C1aC1b PKC $_{\text {was a gift from }}$ Anders Tengholm (Uppsala University)(Wuttke et al., 2013). R-GECO and mito-LAR-GECO were gifts from Robert Campbell (University of Alberta, Addgene plasmid 32444 and 61245) (Wu et al., 2014; Zhao et al., 2011). mApple-Tomm20 was a gift from Michel Davidson (Addgene plamid 54955). TMEM24-mCherry was generated by PCR amplification of human TMEM24 with flanking Nhe1 and EcoR1 followed by ligation into the mCherry-N1 vector using the following primers: TMEM24-Nhe1-fwd, CTAGCTAGCATGGATCCGGGCTGGGGGCA; TMEM24-EcoR1-rev, CCGGAATTCTGAGCTGGGGGCTGGGGTT. All salts, HEPES, poly-L-lysin, EGTA, nitrilotriacetic acid (NTA) and diazoxide were from Sigma-Aldrich. DMEM, Penicillin, streptomycin, glutamine and FBS were from Life technologies. Carbachol, Phorbol 12-Myristate 13-Acetat (PMA), cyanide-p- 
trifluoromethoxyphenylhydrazone (FCCP), rotenone, antimycin A and cyclopiazonic acid (CPA) were from Sigma-Aldrich. Bafilomycin was from TOCRIS Bioscience. Fluo-4-AM, Fura-2-AM and TMRM were from Life Technologies and Cal-520-AM was from AAT Bioquest.

\section{Cell culture and transfection for imaging}

The mouse $\beta$-cell line MIN6 (passages 18-30) (Miyazaki et al., 1990) was cultured in DMEM (Life Technologies) supplemented with $25 \mathrm{mmol} / \mathrm{l}$ glucose, $15 \%$ FBS, $2 \mathrm{mmol} / 1 \mathrm{~L}$-glutamine, $50 \mu \mathrm{mol} / 12$ mercaptoethanol, $100 \mathrm{U} / \mathrm{ml}$ penicillin and $100 \mu \mathrm{g} / \mathrm{ml}$ streptomycin. The cells were kept at $37^{\circ} \mathrm{C}$ and $5 \% \mathrm{CO}_{2}$ in a humidified incubator. Prior to imaging, 0.2 million cells were resuspended in $100 \mu 1$ Opti-MEM-I medium (Life technologies) with $0.2 \mu \mathrm{g}$ plasmid (total) and $0.5 \mu \mathrm{l}$ lipofectamine 2000 (Life technologies) and seeded in the centre of a $25-\mathrm{mm}$ poly-L-lysine-coated coverslip. The transfection reaction was terminated after $4-6 \mathrm{~h}$ by the addition of $2 \mathrm{~mL}$ complete culture medium and cells were imaged 18-24 h later.

\section{Alpha-toxin permeabilization}

Transfected MIN6 cells, grown on 25-mm poly-L-lysine-coated glass coverslips, were incubated with $0.5 \mu \mathrm{M}$ of the AM-ester form of Cal520 for $30 \mathrm{~min}$ at $37^{\circ} \mathrm{C}$. The coverslips were subsequently used as exchangeable bottoms in a modified Sykes-Moore open superfusion chamber that was mounted on the stage of a TIRF microscope (described below) and connected to a peristaltic pump that allowed rapid change of medium. Following change from normal, extracellular-like, medium $(125 \mathrm{mM} \mathrm{NaCl}, 4.9 \mathrm{mM}$ $\mathrm{KCl}, 1.3 \mathrm{mM} \mathrm{MgCl} 2,1.2 \mathrm{mM} \mathrm{CaCl}, 25 \mathrm{mM}$ HEPES, $1 \mathrm{mg} / \mathrm{ml} \mathrm{BSA}$ with $\mathrm{pH}$ set to 7.4) to an intracellular-like medium (see below), the superfusion was interrupted and alpha-toxin was added directly to the chamber (final concentration $\approx 50 \mu \mathrm{g} / \mathrm{mL}$ ). Permeabilization was considered complete when the Cal520 fluorescence had decreased by $>90 \%$, which typically took $2-5 \mathrm{~min}$. Superfusion was then started again and the cells were exposed to intracellular-like buffers containing calibrated $\mathrm{Ca}^{2+}$ concentrations while fluorescence from both remaining Cal520 and mCherry-tagged fusion proteins was recorded. These experiments were performed at ambient temperature $\left(21-23^{\circ} \mathrm{C}\right)$.

\section{Intracellular-like media}

Intracellular-like media with buffered $\mathrm{pH},\left[\mathrm{Ca}^{2+}\right]$ and $\left[\mathrm{Mg}^{2+}\right]$ used in alpha-toxin permeabilization experiments contained: $6 \mathrm{mM} \mathrm{Na}^{+}, 140 \mathrm{mM} \mathrm{K}, 1 \mathrm{mM}$ (free) $\mathrm{Mg}^{2+}, 0-100 \mu \mathrm{M}$ (free) $\mathrm{Ca}^{2+}, 1 \mathrm{mM} \mathrm{Mg}$ ATP, $10 \mathrm{mM}$ HEPES, $2 \mathrm{mM}$ (total) EGTA and $2 \mathrm{mM}$ (total) Nitrilotriacetic acid (NTA) with $\mathrm{pH}$ adjusted to 7.00 at $22^{\circ} \mathrm{C}$ with $2 \mathrm{M} \mathrm{KOH}$. The total concentration of $\mathrm{Ca}^{2+}$ and $\mathrm{Mg}^{2+}$ was calculated using the online version of MaxChelator (http://www.stanford.edu/ cpatton/webmaxcS.htm). Media were made fresh on the day of experiment and kept on ice. To validate the media composition, cells loaded with the $\mathrm{Ca}^{2+}$ indicator Cal520 were mounted on a TIRF microscope, permeabilized and exposed to media with increasing $\mathrm{Ca}^{2+}$ concentrations. From these data a dose-response curve was generated and the $\mathrm{EC}_{50}$ for $\mathrm{Ca}^{2+}$-binding to Cal520 was estimated to be $980 \mathrm{nM}$, an in situ estimation 3-fold higher than the reported in vitro $\mathrm{K}_{\mathrm{D}}$ of $320 \mathrm{nM}$.

\section{TMEM24 knockdown by siRNA}

MIN6 cells were resuspended with $25 \mathrm{nM}$ antiTMEM24 siRNA smartpool (Dharmacon, siGENOME) pre-mixed with $1.6 \mu \mathrm{l} / \mathrm{ml}$ Lipofectamine RNAiMAX (Life technologies) in Opti-MEM I medium. After 3 hours, the Opti-MEM I medium was replaced by DMEM growth medium containing $25 \mathrm{nM}$ siRNA and $1.6 \mu 1 / \mathrm{ml}$ Lipofectamine 3000 (Life technologies) and incubated overnight. Cells transfected with a scrambled sequence siRNA (Dharmacon, siGENOME) following the same procedure were used as controls. After 48 hours, cells were transfected for imaging as described above. The knockdown efficiency was evaluated by western blotting and real-time PCR (see below).

\section{Generation of TMEM24 knockout MIN6 cells by CRISPR/Cas9}

TMEM24 KO MIN6 were generated using a mix of three TMEM24 CRISPR/Cas9 plasmids (Santa Cruz Biotechnology, sc-428047), containing GFP and the following gRNAs:

TTACCATGGTGCGCTCTGAT, CAGCACTCAGCCCGCCATGA and

GTCCCCCGCTGCCGTCTCCA. TMEM24 CRISPR/Cas9 plasmids were transfected into MIN6 by Lipofectamine 3000 (ThermoFisher, L3000015). After 24-hours, single cells positive (knockout) and 
negative (control) for GFP were sorted using a BD FACSariaIII CellSorter and subsequently plated into 96-well plates. Cells were cultured in standard MIN6 growth medium. The clones were tested for the presence of TMEM24 by western blot utilizing anti-TMEM24 antibody (ThermoFisher, A304764A).

\section{TIRF and confocal microscopy}

A medium containing $125 \mathrm{mM} \mathrm{NaCl}, 4.9 \mathrm{mM} \mathrm{KCl}, 1.3 \mathrm{mM} \mathrm{MgCl}_{2}, 1.2 \mathrm{mM} \mathrm{CaCl}_{2}, 25 \mathrm{mM}$ HEPES, 1 $\mathrm{mg} / \mathrm{ml}$ BSA with $\mathrm{pH}$ set to 7.4 at $37^{\circ} \mathrm{C}$ was used in all microscopy experiments. Cells were preincubated in this medium supplemented with $3 \mathrm{mM}$ glucose for $30 \mathrm{~min}$ followed by perifusion with the same medium during recordings. A previously described custom-build prism-type TIRF microscope setup equipped with a 16X/0.8-NA water immersion objective (Nikon) was used to observe large population of cells (Idevall-Hagren et al., 2010). It was built around an E600FN upright microscope (Nikon) enclosed in a Perspex box thermostated at $37^{\circ} \mathrm{C} .491-\mathrm{nm}$ and 561-nm DPSS lasers (Cobolt, Sweden) were used to excite GFP and mCherry, respectively. The laser beams were merged by dichroic mirrors (Chroma Thechnology) and homogenized by a rotating light shaping diffuser (Physic Optics Corps) before being refocused through a dove prism (Axicon) with a $70^{\circ}$ angle to achieve total internal reflection. Laser lines were selected with interference filters (Semrock) in a motorized filter wheel equipped with a shutter (Sutter Instruments) blocking the beam between image captures. Emission light was detected at 530/50 nm (Semrock interference filters) for GFP or 597LP (Melles Griot glass filter) for mCherry using a CCD camera (Hamamatsu ORCA-AG) controlled by MetaFluor software (Molecular Devices). For high resolution TIRF imaging we used an Eclipse TiE microscope (Nikon) equipped with a TIRF illuminator and a $60 \times / 1.45$-NA or $100 \times / 1.49-\mathrm{NA}$ objectives as previously described (Xie et al., 2019). Confocal microscopy was performed on an Eclipse TE2000 microscope (Nikon) equipped with a Yokogawa CSU-10 spinning disc confocal unit and a 100×/1.49-NA plan Apochromat objective (Nikon) (Idevall-Hagren et al., 2013). Briefly GFP and mCherry were excited by 491-nm and 561-nm DPSS lasers (Cobolt, Sweden) and were detected through 530/50 nm interference filter and 597LP filter, respectively, through a black-illuminated EMCCD camera (DU-888; Andor Technology).

\section{Fluorescence recovery after photobleaching (FRAP)}

TIRF-FRAP was performed on a Nikon TiE microscope equipped with an iLAS2 TIRF illuminator for multi-angle patterned illumination (Cairn Research) and a 100X1.49-NA Apo-TIRF objective.

Excitation light for GFP and mCherry was delivered by 488-nm and 561-nm diode-pumped solid-state lasers with built-in acousto-optical modulators, and light for bleaching was delivered by a $405-\mathrm{nm}$ DPSS laser (all from Coherent). Fluorescence was detected with a back-illuminated EMCCD camera (DU-897, Andor Technology) controlled by MetaMorph (Molecular Devices). Emission wavelengths were selected with filters $(527 / 27 \mathrm{~nm}$ for GFP and $590 \mathrm{~nm}$ long-pass for mCherry) mounted in a filter wheel (Sutter Instruments). Cells were mounted in an open perfusion chamber with temperature held at $37^{\circ} \mathrm{C}$. Following a $10 \mathrm{~s}$ baseline acquisition, a $3 \times 3 \mu \mathrm{m}$ area within the cells was exposed to a $100 \mathrm{~ms}$ $405-\mathrm{nm}$ light pulse to bleach the fluorophores, followed by continued acquisition for $120 \mathrm{~s}$ at $4 \mathrm{fps}$. Calculations of the mobile fraction $(M f)$ of each fluorescent protein was performed using the following formula:

$$
M f=100 * \frac{(\mathrm{F} p c-\mathrm{Fbg})}{(\mathrm{F} \infty c-\mathrm{F} b g)} * \frac{((\mathrm{F} \infty-\mathrm{F} b g)-(\mathrm{F} 0-\mathrm{F} b g))}{((\mathrm{F} p-\mathrm{F} b g)-(\mathrm{F} 0-\mathrm{F} b g))}
$$

$\mathrm{F} p c$ (whole cell pre-bleach intensity), Fp (bleach ROI pre-bleach intensity), Foc (asymptote of fluorescence recovery of the whole cell), Fbg (mean background intensity), $\mathrm{F} \infty$ (asymptote of the bleach ROI), F0 (bleach ROI post-bleach intensity).

\section{Western blot analysis}

After 3-time wash with phosphate-buffered salin (PBS), MIN6 cells were homogenized and lysed in RIPA buffer (50mM Tris-HCl, pH=7.4, 1\% NP-40, 0.5\% Na-deoxycholate, $0.1 \%$ SDS, $150 \mathrm{mM}$ EDTA), placed on ice for $30 \mathrm{~min}$ or agitated on a rotator at $4^{\circ} \mathrm{C}$ for $30 \mathrm{~min}$. Cell lysates were mixed with $3 \times$ sample buffer $(6 \%$ SDS, $15 \%$ 2-mercaptoethanol, 30\% glycerol, $0.006 \%$ bromophenol blue, $0.15 \mathrm{M}$ Tris- $\mathrm{HCl}$ ) and boiled at $95^{\circ} \mathrm{C}$ for $10 \mathrm{~min}$. Protein content was determined by a detergent- 
compatible protein assay (Bio-Rad, Hercules, CA, USA) and proteins were separated by SDS-PAGE (5-20\%) and blotted onto PVDF membrane using semi-dry transfer. Membranes were blocked in 4\% milk dissolved in TBS-Tween $(0.1 \%$ Tween 20$)$. The following antibodies and dilutions were used: anti-TMEM24 (Bethyl Laboratories,1:1000), anti-GAPDH (Cell Signaling Technology,1:1000), antiRabbit secondary antibody (GE healthcare,1:10000). Membranes were developed by the Odyssey Fc Imaging system (LI-COR Bioscience).

\section{Quantitative RT-PCR}

mRNA from control and TMEM24 knockdown cells were extracted using the NucleoSpin RNAPlus kit (Macherey-Nagel). RT-PCR was performed by QuantiTect SYBR Green RT-PCR kit (Qiagen) using the following primer: GAPDH-fwd, ACTCCACTCACGGCAAATTC-3; GAPDH-rev,TCT CCATGGTGGTGAAGACA; TMEM24-fwd, CGCCCAGAACTCAGCCTAAA, TEME24-rev GGGTAGGTCTGGGGATGGAT. PCR reaction was done by Light Cycler 2.0 (Roche). Results are presented as $\Delta \Delta \mathrm{C}_{\mathrm{t}}$, normalized by GAPDH expression in control and TMEM $24 \mathrm{KD}$ cells.

\section{Insulin secretion measurements}

Insulin secretion was measured from monolayers of MIN6 cells grown in 12-well plates. $4 \times 10^{5}$ control or TMEM 24 knockdown cells were prepared as describe above in 12-well plates 72 hours before secretion measurements. Cells were pre-incubated in $3 \mathrm{mM}$ glucose imaging buffer at $37^{\circ} \mathrm{C}$ for 30 min. Cells were subsequently incubated in buffers containing $3 \mathrm{mM}$ glucose, $20 \mathrm{mM}$ glucose or $3 \mathrm{mM}$ glucose supplemented with $30 \mathrm{mM} \mathrm{KCl}$, immediately followed by buffer collection. In the end, cells were released by the addition of $80 \mu \mathrm{l}$ typsin and mixed with $120 \mu \mathrm{l}$ complete growth medium. $100 \mathrm{ul}$ of the collected cell suspension was mixed with $100 \mu 1$ acidic ethanol, sonicated on ice and neutralized by the addition of $900 \mu \mathrm{L}$ Tris buffer ( $\mathrm{pH} 8)$ to determine insulin content. The insulin concentration in the samples was measured by a mouse insulin AlphaLISA kit (Perkin-Elmer).

\section{Oxygen consumption rates measurement}

The oxygen consumption rate (OCR) in MIN6 cells were monitored by an Extracellular Flux Analyzer (XFe96, Agilent Tchnologies, CA, USA). $3 \times 10^{4}$ cells (wildtype and TMEM24 KO) were seeded in each well of XFe96 microplates and cultured for 24 additional hours. Cells were thereafter preincubated with Seahorse XF DMEM (Agilent Technologies) containing $3 \mathrm{mM}$ glucose (pH 7.4) for $1 \mathrm{~h}$ at $37^{\circ} \mathrm{C}$ before the microplate was inserted into the XFe96 Analyzer. For each experiment, 4-6 replicates of each treatment were measured. OCR at $3 \mathrm{mM}$ glucose was measured for 30 minutes, followed by another 30 minutes with either $3 \mathrm{mM}$ or $20 \mathrm{mM}$ glucose. Then, the proportions of respiration driving ATP synthesis and proton leak were determined by blocking ATP synthase with 2 $\mu \mathrm{M}$ oligomycin (Sigma-Aldrich). Subsequently, $2 \mu \mathrm{M}$ of the mitochondrial uncoupler cyanide-ptrifluoromethoxyphenylhydrazone (FCCP) was added to determine the maximal respiratory capacity. Lastly, $2 \mu \mathrm{M}$ rotenone and $5 \mu \mathrm{M}$ antimycin A were added together to block transfer of electrons from the mitochondrial respiratory chain complex I and III to determine the remaining non-mitochondriadependent respiration. To calculate the mitochondrial respiration, non-mitochondrial OCR was subtracted from the total OCR. Data was normalized to protein content which was determined by the DC protein assay (Bio-Rad Laboratories, USA).

\section{Measurements of mitochondrial membrane potential}

The mitochondrial membrane potential $\left(\Delta \Psi_{\mathrm{m}}\right)$ was monitored by the lipophilic cationic dye tetramethylrhodamine methyl ester (TMRM) via fluorescence time-lapse imaging using an inverted microscope (Eclipse TE2000U; Nikon, Kanagawa, Japan). The epifluorescence microscope is equipped with a high-power LED light source (Omicron LedHUB; Photonlines Ltd, Newcatle, UK) which, connected with a 5-mm diameter liquid light guide, provided excitation light at $540 \mathrm{~nm}$. Emission was measured at $560 \mathrm{~nm}(5 \mathrm{~nm}$ half-bandwidth) and the fluorescence signal was detected by an Evolve EMCCD camera (Photometrics, Arizona, USA). MetaFluor software (Molecular Devices Corp.) allowed to control the microscope setup and to acquire images every 5 seconds. Prior to imaging, the cells were seeded onto $25 \mathrm{~mm}$ round coverslips and loaded with TMRM at $10 \mathrm{nM}$ during a 30-min incubation at $37^{\circ} \mathrm{C}$ in an imaging buffer containing $125 \mathrm{mM} \mathrm{NaCl}, 5 \mathrm{mM} \mathrm{KCl}, 1.3 \mathrm{mM}$ $\mathrm{CaCl}_{2}, 1.2 \mathrm{mM} \mathrm{MgCl}_{2}$, and $25 \mathrm{mM}$ HEPES with $\mathrm{pH}$ adjusted to 7.40 with $\mathrm{NaOH}$. The coverslips were 
placed on the bottom of an open Sykes-More chamber. On the top of the coverslip, a thin $25-\mathrm{mm}$ diameter stainless steel plate with a 4-mm wide and 7-mm long opening pressed the 1-mm thick silicon rubber gasket with identical dimensions and central opening to the coverslip. The temperature of the chamber holder and the CFI S Fluor $40 \times 1.3$ numerical aperture oil immersion objective (Nikon) was stable at $37^{\circ} \mathrm{C}$ during the experiment using custom-built thermostats. Fixed on the stainless-steel plate, inlet and outlet cannulas maintained a laminar superfusion at a rate of $2.0 \mathrm{ml} / \mathrm{min}$ with the imaging buffer containing $10 \mathrm{nM}$ TMRM.

\section{Measurement of cytoplasmic, mitochondrial and endoplasmic reticulum $\left[\mathrm{Ca}^{2+}\right]$}

Cytosolic $\left[\mathrm{Ca}^{2+}\right]$ was measured on an epifluorescence microscope setup (described above) using the ratiometric dye Fura- 2 or the green-fluorescent dye Cal520. The cells were preincubated for 30 min at $37^{\circ} \mathrm{C}$ in imaging buffer supplemented with $1 \mu \mathrm{M}$ of the indicator, followed by repeated washing in imaging buffer and imaging. Mitochondrial $\mathrm{Ca}^{2+}$ was measured using the genetically-encoded red fluorescent, low affinity indicator mito-LAR-GECO (Wu et al., 2014), while $\mathrm{ER} \mathrm{Ca}^{2+}$ was measured using the FRET-based indicator D4ER (Ravier et al., 2011). Both indicators were delivered to cells by transient transfection as described above, and experiments were performed 18-36h post-transfection.

\section{Morphometric analysis of mitochondria}

To determine the morphology of the mitochondria, wildtype MIN6 cells and TMEM24 KO cells expressing mApple-Tomm 20 were observed under the spinning-disc confocal microscope. The images were analyzed with the open-source image analysis software CellProfiler (Carpenter et al., 2006) using several modules that were placed in a sequential order to create a flexible image analysis pipeline. First, processing filters were applied to enhance the fluorescence signal of the regions that display higher intensity relative to its immediate neighborhood. This allowed the better identification of the mitochondria as separate objects during the following module. The Otsu's automatic threshold method permitted the assignment of the threshold value by including the pixels of the image either in the "background" class or the "foreground" class. The objects/mitochondria detected using the pipeline were not de-clumped to enable the identification of potential network formation, and the size and shape of the mitochondria was determined and the data was exported to Microsoft Excel. Eccentricity, which distinguish mitochondria based on shape from tubular (1) to circular (0), was used as an overall determinant of the mitochondria shape.

\section{Image analysis}

TIRF microscopy and confocal microscopy images were analyzed offline by Fiji (Schindelin et al., 2012). To determine fluorescence changes, the regions of interest and background regions were first manually identified. Fluorescence intensity changes within these regions were recorded and the data was exported to Excel. All data points were background corrected and normalized to the initial fluorescence intensity $\left(\mathrm{F} / \mathrm{F}_{0}\right)$.

\section{Statistical analysis}

One-way ANOVA followed by Tukey's Post hoc test, Mann-Whitney U-test (for non-parametric data) or Student t-test were used.

\section{RESULTS}

\section{TMEM24 plasma membrane binding is controlled by $\mathrm{DAG}$ and $\mathrm{Ca}^{2+}$}

To better understand the role of TMEM24 in the regulation of $\beta$-cell function, we investigated conditions that promote TMEM24 dissociation from the plasma membrane. Elevation of the glucose concentration from 3 to $20 \mathrm{mM}$ in clonal MIN6 $\beta$-cells resulted in regular cytosolic $\mathrm{Ca}^{2+}$ oscillations with elevations mirrored by synchronized TMEM24-GFP dissociations, seen as reductions in plasma membrane-proximal fluorescence by TIRF microscopy (Fig. 1A-C). Direct depolarization with $30 \mathrm{mM}$ $\mathrm{KCl}$ also caused dissociation of TMEM24 from the plasma membrane, consistent with voltagedependent $\mathrm{Ca}^{2+}$ influx being the trigger for dissociation (Fig. 1B-D). Similar TMEM24 dissociation was also seen in response to carbachol, which activate phospholipase $\mathrm{C}$ and trigger IP3-mediated 
release of $\mathrm{Ca}^{2+}$ from the ER (Fig. 1B, C). Passive depletion of ER $\mathrm{Ca}^{2+}$ using the SERCA inhibitor cyclopiazonic acid (CPA) also triggered TMEM24 dissociation, although less prominent than in response to carbachol (Fig. 1B, C). TMEM24 dissociation has previously been shown to depend on PKC-mediated phosphorylation of C-terminal residues in the molecule (Lees et al., 2017). Although $\mathrm{Ca}^{2+}$ is a potent activator of PKC, some isoforms also require diacylglycerol (DAG). To determine to what extent DAG is involved in the spatial control of TMEM24, we stimulated MIN6 cells with $1 \mu \mathrm{M}$ DAG analogue Phorbol 12-Myristate 13-Acetat (PMA). This resulted in an immediate dissociation of TMEM24 from the plasma membrane without apparent change in the cytosolic $\mathrm{Ca}^{2+}$ concentration (Fig. 1B, C and Suppl. Fig. 1A). To further uncouple DAG formation from $\mathrm{Ca}^{2+}$ changes we first exposed cells to CPA to deplete $\mathrm{ER} \mathrm{Ca}^{2+}$ stores, followed by addition of carbachol to activate PLC and increase plasma membrane DAG. CPA caused an increase in cytosolic $\mathrm{Ca}^{2+}$ and a slight dissociation of GFP-TMEM24 from the plasma membrane. The subsequent addition of carbachol resulted in a pronounced dissociation of TMEM24 that occurred in the absence of noticeable changes in cytosolic $\mathrm{Ca}^{2+}$ concentration (Suppl. Fig. 1B). These results indicate that TMEM24 is spatially controlled by both $\mathrm{Ca}^{2+}$ and DAG. We also noticed that whereas carbachol caused a homogenous dissociation of TMEM24 from the plasma membrane (Fig. 1E, right panels), the dissociation in response to direct depolarization with $\mathrm{KCl}$ were instead incomplete, more heterogenous and differed between subregions of the plasma membrane within the same cell (Fig. 1E, left panels). This pattern resembles that of a diacylglycerol (DAG) biosensor (GFP-C $1 \mathrm{aCl} \mathrm{b}_{\mathrm{PKC}}$ ) reporting DAG formation after autocrine activation of purinergic P2Y1 receptors by ATP co-secreted with insulin from the cells (Wuttke et al., 2013) (Suppl. Fig. 1C, D). Because of the close interplay between DAG and $\mathrm{Ca}^{2+}$, we determined the effect of known $\mathrm{Ca}^{2+}$ concentrations on TMEM24-mCherry plasma membrane binding in $\alpha$-toxinpermeabilized MIN6 cells in which changes in $\mathrm{Ca}^{2+}$ could easily be uncoupled from those in DAG. We found that dissociation of TMEM24 occurred with an $\mathrm{EC}_{50} 358 \pm 70 \mathrm{nM}(\mathrm{n}=13)$ and maximal effect at $30 \mu \mathrm{M}$ (Fig. 1F, G). Addition of $1 \mu \mathrm{M}$ PMA caused pronounced dissociation of TMEM24 from the plasma membrane and subsequent stepwise increase in the $\mathrm{Ca}^{2+}$ concentration had little effect on TMEM24 plasma membrane binding (Suppl. Fig. 1E). For comparison, the plasma membrane binding of E-Syt1-mCherry, another $\mathrm{Ca}^{2+}$-dependent ER-PM contact protein, was triggered at $1 \mu \mathrm{M}$ $\mathrm{Ca}^{2+}$ and maximal at $10 \mu \mathrm{M} \mathrm{Ca}^{2+}\left(\mathrm{EC}_{50} 1.99 \pm 0.51 \mu \mathrm{M}, \mathrm{n}=6\right)$ (Fig. 1G). When comparing the plasma membrane fluorescence intensity of TMEM24-mCherry in intact cells and following permeabilization in a $\mathrm{Ca}^{2+}$-free buffer, we found that removal of $\mathrm{Ca}^{2+}$ promoted further association of TMEM24 with the plasma membrane $(13 \pm 5 \%$ increase in plasma membrane TMEM24-mCherry fluorescence, $n=22)$ (Fig. 1H) while the opposite was observed for GFP-E-Syt1 $(29 \pm 4 \%$ drop in plasma membrane fluorescence, $n=31$ ). These results indicate that TMEM24 plasma membrane binding may be partially reduced already at resting $\mathrm{Ca}^{2+}$ concentrations. Fluorescence recovery after photobleaching (FRAP) analysis revealed that TMEM24-GFP, although enriched at ER-PM contacts, exhibited pronounced dynamics with a large proportion belonging to a mobile fraction (Fig. 1I). Taken together, these results show that the association of TMEM24 with the plasma membrane is regulated by both DAG and $\mathrm{Ca}^{2+}$, and that dissociation is triggered already by modest nanomolar $\mathrm{Ca}^{2+}$ concentrations, resulting in relatively weak interactions between TMEM 24 and the plasma membrane. 

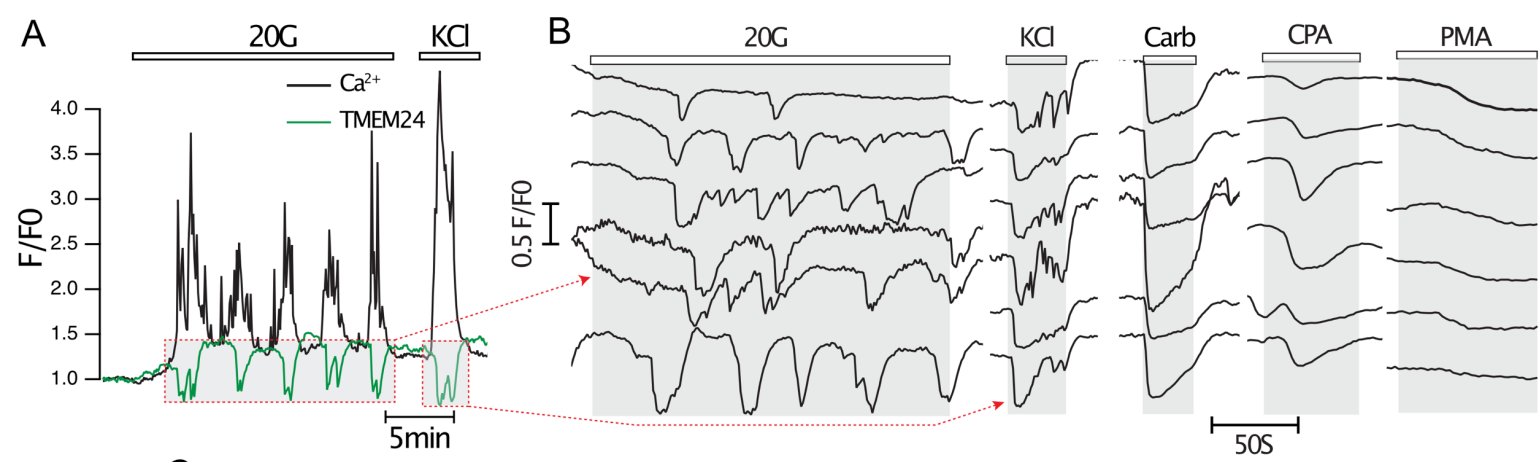

C

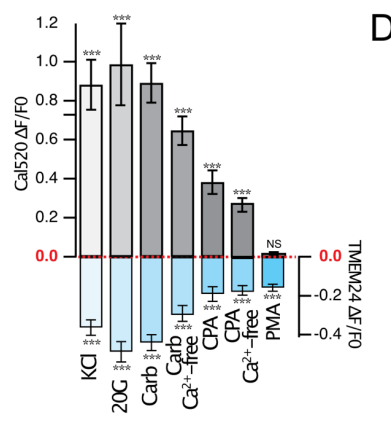

$\mathrm{D}$
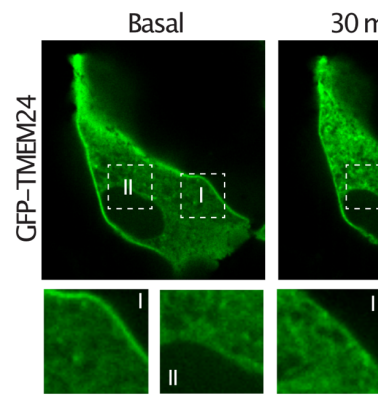

$\mathrm{F}$

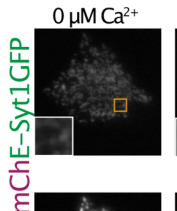

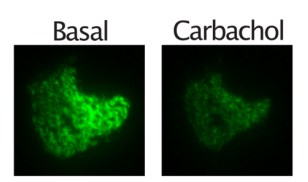
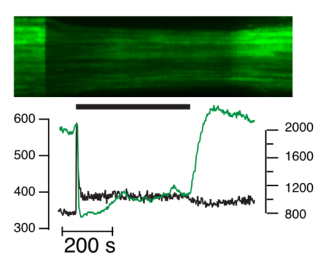

$30 \mathrm{mM} \mathrm{KCl}$
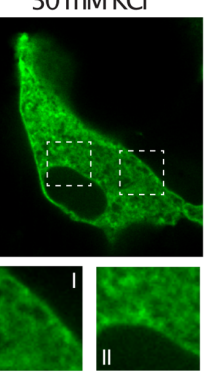
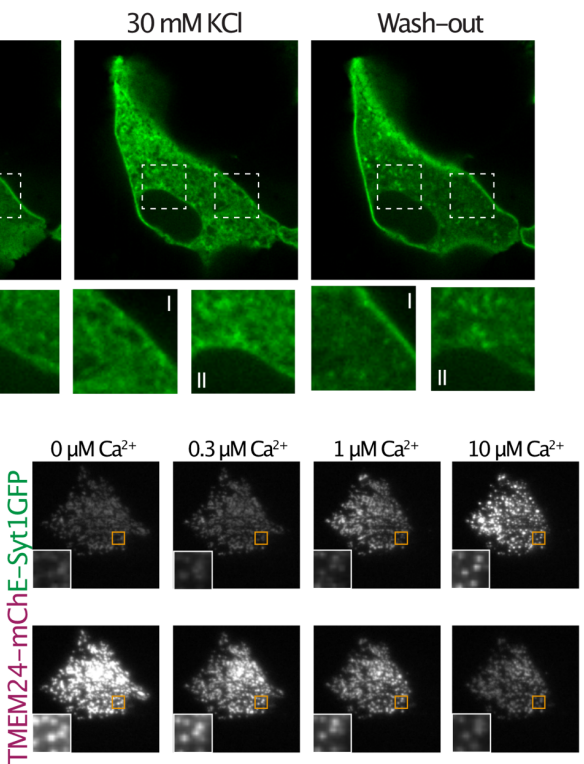

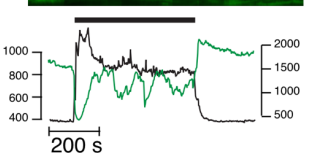

G

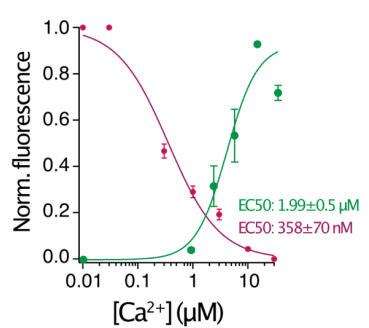

$\mathrm{H}$

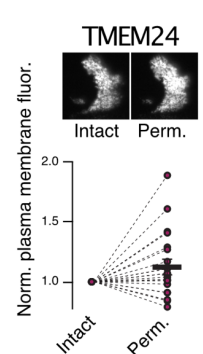

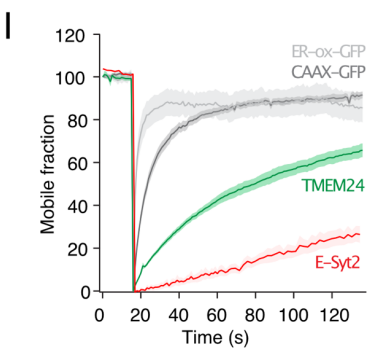

Figure 1. TMEM24 plasma membrane binding is controlled by DAG and $\mathrm{Ca}^{2+}$.

(A) TIRF microscopy recording of $\mathrm{Ca}^{2+}$ indicator Cal520 (black) and TMEM24-EGFP (green) fluorescence from a single MIN6 cell stimulated with $20 \mathrm{mM}$ glucose $(20 \mathrm{G})$ and $30 \mathrm{mM} \mathrm{KCl}$.

(B) Representative TIRF microscopy recordings from TMEM24-EGFP expressing MIN6 cells in response to $20 \mathrm{mM}$ glucose, $30 \mathrm{mM} \mathrm{KCl}, 100 \mu \mathrm{M}$ carbachol, $100 \mu \mathrm{M} \mathrm{CPA}$ and $1 \mu \mathrm{M}$ PMA.

(C) Quantification of $\mathrm{Ca}^{2+}$ increases (grey) and the corresponding magnitude of TMEM24-EGFP dissociation from the plasma membrane (blue), $\mathrm{n}=20$ cells for each group. ${ }^{* *} \mathrm{P}<0.001$ for comparison to 0 .

(D) Confocal microscopy images of a MIN6 cell expressing TMEM24-EGFP. Images were taken before, during and $30 \mathrm{~s}$ after depolarization. Content within the dashed boxes are magnified below.

(E) TIRF microscopy images of two MIN6 cells expressing TMEM24-EGFP. Pictures to the left shows a cell before and $30 \mathrm{~s}$ after the addition of $30 \mathrm{mM} \mathrm{KCl}$ and pictures to the right shows a cell before and 30 $\mathrm{s}$ after addition of $100 \mu \mathrm{M}$ carbachol. Shown below are kymographs of TMEM24-EGFP fluorescence from lines drawn across each cell and TIRF microscopy recordings from the cells (black trace, Cal520 fluorescence; green trace, TMEM24-EGFP fluorescence) 
(F) TIRF microscopy images of MIN6 cells loaded with the $\mathrm{Ca}^{2+}$ indicator Cal520 and expressing E-Syt1GFP (top) or TMEM24-mCherry (bottom) following $\alpha$-toxin permeabilization and exposure to the indicated $\mathrm{Ca}^{2+}$ buffers.

(G) Dose-response curves of $\mathrm{Ca}^{2+}$ induced TMEM24-mCherry (magenta) and E-Syt1-GFP (green) fluorescens changes in $\alpha$-toxin permeabilized MIN6 cells ( $\mathrm{n}=42$ cells).

(H) TIRF microscopy images of a MIN6 cell expressing TMEM24-mCherry before (intact) and after $\alpha$ toxin permeabilization (perm). Quantifications below show the plasma membrane fluorescence change that occurred following $\alpha$-toxin permeabilization in a $\mathrm{Ca}^{2+}$-deficient buffer.

(I) TIRF microscopy recordings of ER-oxGFP (ER luminal protein; light grey), GFP-CaaX (prenylated protein anchored in the plasma membrane; dark grey), TMEM24-EGFP (green) and E-Syt2-GFP (red) fluorescence recovery after photobleaching (FRAP). Bar graph to the right shows the mobile fraction of each fluorescently-tagged protein.

All data are presented as mean \pm SEM, ${ }^{* * *} \mathrm{p}<0.001$

\section{TMEM24 is not required for glucose-stimulated insulin secretion}

TMEM24 has previously been reported to be required for glucose-stimulated $\mathrm{Ca}^{2+}$ influx and insulin release, although the mechanisms are unclear (Lees et al., 2017). To examine its role in more detail, we reduced TMEM24 expression in MIN6 cells by siRNA-mediated transient knockdown. such knockdown resulted in $61.2 \pm 6.3 \%(\mathrm{n}=4, \mathrm{P}<0.01)$ reduction in TMEM 24 expression as assessed by Western blotting ( $86.7 \pm 5.2 \%$ reduction as assessed by qRT-PCR) (Fig. 2A). We next determined the impact of reduced TMEM24 expression on $\mathrm{Ca}^{2+}$ handling using the fluorescent $\mathrm{Ca}^{2+}$ indicator Cal520. In control cells, elevation of the glucose concentration from 3 to $20 \mathrm{mM}$ resulted in rapid lowering of the cytosolic $\mathrm{Ca}^{2+}$ concentration $(-17.1 \pm 0.9 \%, \mathrm{n}=148)$ due to ATP-driven sequestration of the ion into the ER (ref), followed after $2.8 \pm 0.09$ minutes by a pronounced $\mathrm{Ca}^{2+}$ increase and sustained elevation (Fig. 2B, C, E). Most cells showed slow, regular $\mathrm{Ca}^{2+}$ oscillations in the continued presence of $20 \mathrm{mM}$ glucose, while a smaller number showed more irregular responses (Fig. 2B). In TMEM24 KD cells, the initial $\mathrm{Ca}^{2+}$ lowering in response to $20 \mathrm{mM}$ glucose was less pronounced $(-12.4 \pm 0.8 \%, \mathrm{n}=137$, $\mathrm{P}=0.0016$ for comparison to control) and was followed after $3.31 \pm 0.11 \mathrm{~min}(\mathrm{n}=141, \mathrm{P}=0.003$ for comparison to control) by a sustained rise of $\mathrm{Ca}^{2+}$ with regular oscillations (Fig. 2B, C, E). The timeaverage increase in $\mathrm{Ca}^{2+}$ was slightly higher in TMEM24 KD cells compared to controls (Fig. 2C, D). Overexpression of TMEM24 resulted in an exaggerated initial lowering of the cytosolic $\mathrm{Ca}^{2+}$ concentration in response to glucose and a slightly increased sustained $\mathrm{Ca}^{2+}$ response when compared to non-transfected control cells (Fig. 2C-E). To ascertain that the relatively mild effect on $\mathrm{Ca}^{2+}$ handling in TMEM24 KD cells was not due to remaining low TMEM24 expression, we generated TMEM24 knockout MIN6 cell lines using CRISPR/Cas9 (Fig. 2F). Both control and TMEM24 KO cells exhibited subsequent oscillations in the cytosolic $\mathrm{Ca}^{2+}$ concentration, although the time-averaged $\mathrm{Ca}^{2+}$ increase was reduced by $21 \pm 2 \%(\mathrm{n}=497, \mathrm{P}=1.47 \mathrm{E}-9)$ in the TMEM24 KO cells (Fig. 2G-I). Similar to TMEM24 KD, the KO cell line also exhibited strongly suppressed initial $\mathrm{Ca}^{2+}$ lowering in response to glucose (Fig. 2J, K). Both TMEM24 KD and TMEM24 KO cells exhibited $\mathrm{Ca}^{2+}$ responses to glucose that contained a component of rapid $\mathrm{Ca}^{2+}$ transients superimposed on top of the regular, slow $\mathrm{Ca}^{2+}$ oscillations (Fig. 2B, G).

Given the relatively small of effect of TMEM $24 \mathrm{KD}$ or $\mathrm{KO}$ on glucose-induced $\mathrm{Ca}^{2+}$ influx observed here, we decided to reinvestigate the previously proposed fundamental role of TMEM24 in insulin secretion (Lees et al., 2017; Pottekat et al., 2013). Using insulin ELISA we found that basal secretion at $3 \mathrm{mM}$ glucose and that stimulated by $20 \mathrm{mM}$ were similar in control and TMEM24 KD and KO cells (Fig. 2N). There was also no difference in insulin content between control cells and TMEM24 $\mathrm{KD}$ or KO cells (Fig. 2L, M). These results indicate that TMEM24 is dispensable for the acute regulation of glucose-stimulated insulin secretion. 

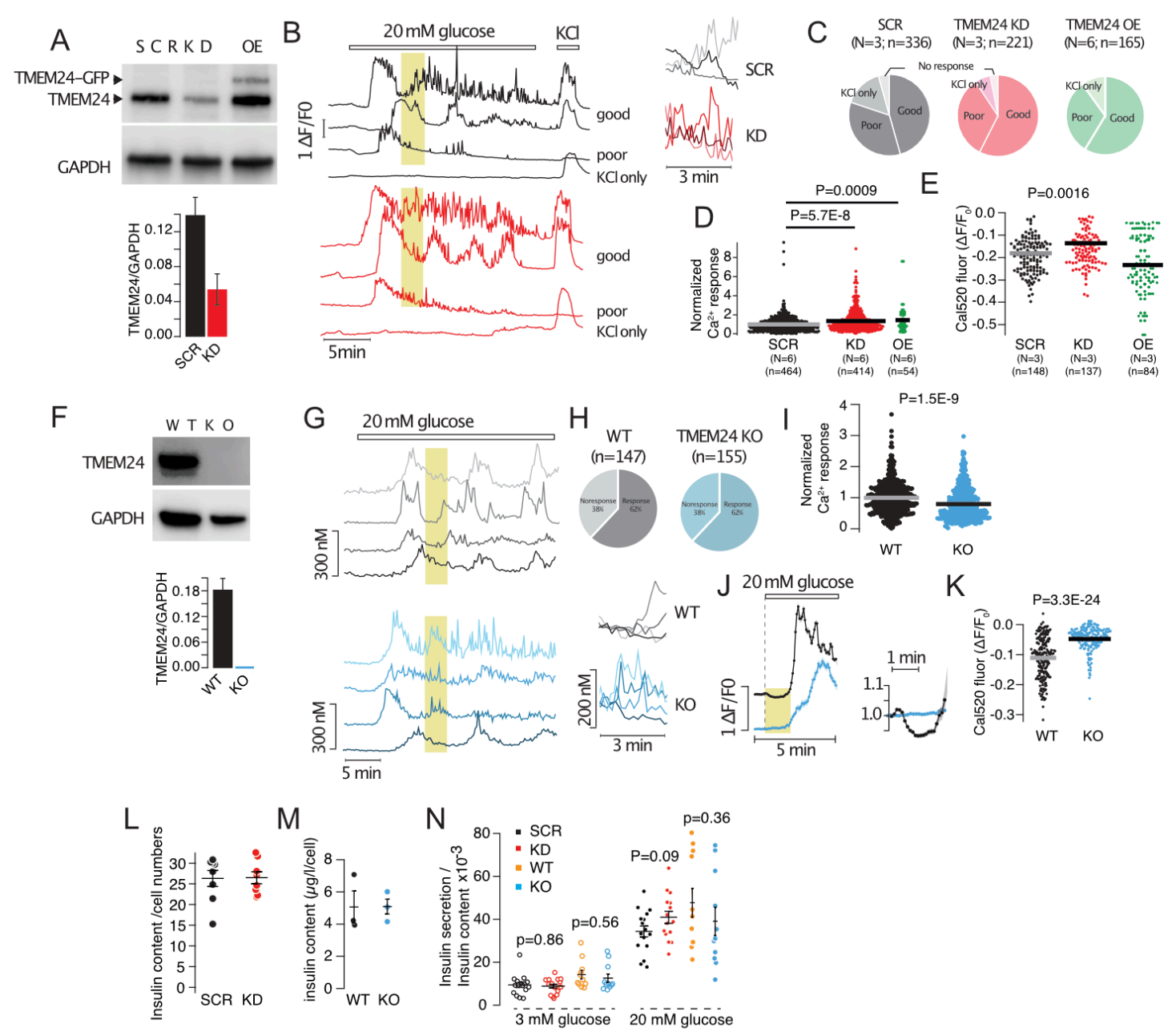

Figure 2. TMEM24 is not essential for glucose-induced $\mathrm{Ca}^{2+}$ signaling or insulin secretion.

(A) Western blot of lysates from MIN6 cells transfected with control (SCR) or anti-TMEM24 siRNA (KD) alone or together with TMEM24-EGFP (+TMEM24-EGFP) probed with anti-TMEM24 and GAPDH antibodies. Quantifications of densitometric measurements are shown below $(\mathrm{n}=4)$.

(B) Representative $\mathrm{Ca}^{2+}$ recordings (Fluo-4) from control (black) and TMEM24 KD (red) MIN6 cells in response to $20 \mathrm{mM}$ glucose and $30 \mathrm{mM} \mathrm{KCl}$. The cells were divided into three groups based on the type of response: 'good'; continuous response to glucose and robust response to $\mathrm{KCl}$, 'poor'; initial, but not sustained, response to glucose and robust response to $\mathrm{KCl}$, 'KCl only'; no response to glucose but robust response to $\mathrm{KCl}$. The boxed yellow areas are shown to the right on an expanded time-scale.

(C) Pie chart showing the distribution of $\mathrm{Ca}^{2+}$ responses in control (black), TMEM24 KD (red) and TMEM24-EGFP expressing (green) MIN6 cells.

(D) Time-average Fluo-4 fluorescence change in response to $20 \mathrm{mM}$ glucose in control (SCR, black), TMEM24 KD (KD, red) and TMEM24-EGFP expressing (OE, green) MIN6 cells.

(E) Quantifications of the initial, glucose-induced lowering of Fluo-4 fluorescence in control (SCR, black), TMEM24 KD (KD, red) and TMEM24-EGFP expressing (OE, green) MIN6 cells.

(F) Western blot of lysates from wildtype and TMEM24 KO MIN6 cells probed with anti-TMEM24 and GAPDH antibodies. Quantifications of densitometric measurements are shown below $(\mathrm{n}=2)$.

(G) Representative $\mathrm{Ca}^{2+}$ recordings (Fura-2) from control (black) and TMEM24 KO (blue) MIN6 cells in response to $20 \mathrm{mM}$ glucose. The cells were divided into two groups based on the absence or presence of $\mathrm{Ca} 2+$ increase in response to glucose. The boxed yellow areas are shown to the right on an expanded time-scale.

(H) Pie chart showing the distribution of $\mathrm{Ca}^{2+}$ responses in wildtype (black), TMEM24 KO (blue) MIN6 cells.

(I) Time-average $\mathrm{Ca}^{2+}$ response to $20 \mathrm{mM}$ glucose in wildtype (black) and TMEM24 $\mathrm{KO}$ (blue) cells.

(J) Initial $\mathrm{Ca}^{2+}$ response to $20 \mathrm{mM}$ glucose in wildtype (black) and TMEM24 KO (blue) cells. Data presented as means \pm SEM for 63 (wildtype) and 52 (KO) cells from one experiment. The yellow area is shown to the right on an expanded time-scale. 
(K) Quantifications of the initial, glucose-induced lowering of Cal520 fluorescence in wildtype (black) and TMEM24 KO (blue) MIN6 cells.

(L,M) Insulin content in control and TMEM24 KD cells (L) and in wildtype and TMEM24 KO cells (M). (N) Insulin secretion in control (black), TMEM24 KD (red), wildtype (yellow) and TMEM24 KO cells in response to $3 \mathrm{mM}$ and $20 \mathrm{mM}$ glucose.

\section{TMEM24 controls ER $\mathrm{Ca}^{2+}$ homeostasis}

Since we observed a slightly impaired $\mathrm{Ca}^{2+}$ response to glucose in TMEM24 KO cells, we tested to what extent $\mathrm{Ca}^{2+}$ influx in response to direct depolarization was affected by the loss of TMEM24. The resting cytosolic $\mathrm{Ca}^{2+}$ concentration was similar in wildtype and TMEM24 KO cells. Depolarization with $30 \mathrm{mM} \mathrm{KCl}$ resulted in an immediate rise of cytosolic $\mathrm{Ca}^{2+}$ that averaged $361 \pm 5 \mathrm{nM}(\mathrm{n}=298)$ in wildtype cells. This response was increased to $441 \pm 8 \mathrm{nM}(\mathrm{n}=317, \mathrm{P}=3.12 \mathrm{E}-16)$ in TMEM24 KO cells (Fig. 3A, B). Consistent with more $\mathrm{Ca}^{2+}$ entering the cells in response to depolarization, we also found that insulin secretion in response to acute depolarization was increased by $60 \%$ in TMEM 24 KO cells $(\mathrm{n}=12, \mathrm{P}=0.019)$ (Fig. 3G). Similar results were obtained from cells where TMEM24 expression had instead been reduced by siRNA (Fig. 3D, E, H). Several observations made in TMEM24 KO cells, such as lack of initial $\mathrm{Ca}^{2+}$-lowering effect of glucose and the appearance of irregular $\mathrm{Ca}^{2+}$ spikes, pointed to potential changes in the ability of the ER to sequester and mobilize $\mathrm{Ca}^{2+}$. To test this more directly, we mobilized $\mathrm{Ca}^{2+}$ from the ER by the SERCA inhibitor CPA in the absence of extracellular $\mathrm{Ca}^{2+}$ while measuring changes in the cytosolic $\mathrm{Ca}^{2+}$ concentration. The addition of CPA resulted in a $32 \pm 1 \mathrm{nM}(\mathrm{n}=298)$ increase in the cytosolic $\mathrm{Ca}^{2+}$ concentration, reflecting the release of $\mathrm{Ca}^{2+}$ from the ER. This release was increased to $48 \pm 2 \mathrm{nM}(\mathrm{n}=306, \mathrm{P}=9.8 \mathrm{E}-12)$ in TMEM24 KO cells (Fig. 3I, J). The addition of $10 \mathrm{mM} \mathrm{Ca}^{2+}$ to the extracellular buffer triggered store-operated $\mathrm{Ca}^{2+}$ entry, which was not different in the two cell lines (Fig. 3K). Similar results were obtained when $\mathrm{ER} \mathrm{Ca}^{2+}$-store depletion was instead triggered by the addition of thapsigargin in the presence of extracellular $\mathrm{Ca}^{2+}$, and the response in TMEM24 KO cells was normalized by the re-expression of wildtype TMEM24 (Fig. 3L). Direct measurements of ER $\mathrm{Ca}^{2+}$ using the FRET-based $\mathrm{Ca}^{2+}$ sensor D4ER confirmed that the ER of TMEM24 KO cells contained more $\mathrm{Ca}^{2+}$ than that of wildtype cells under resting conditions, and also that more $\mathrm{Ca}^{2+}$ was released from the ER following SERCA inhibition with CPA (Fig. 3M, $\mathrm{N})$. We speculated that perhaps the larger rise of cytosolic $\mathrm{Ca}^{2+}$ in response to depolarization in TMEM24 KO cells might be due to simultaneous $\mathrm{Ca}^{2+}$-induced $\mathrm{Ca}^{2+}$-release from the ER. To test this alternative, we performed experiments where cytosolic $\mathrm{Ca}^{2+}$ was measured following two brief applications of $30 \mathrm{mM} \mathrm{KCl}$, where the second application was preceded by SERCA inhibition with thapsigargin. Consistent with previous observations (Chen et al., 2003) prevention of $\mathrm{Ca}^{2+}$ sequestration into the ER by SERCA inhibition resulted in a more pronounced depolarization-induced $\mathrm{Ca}^{2+}$ increase in wildtype cells (Fig. 3N, O). This augmentation was even more apparent in TMEM24 $\mathrm{KO}$ cells, and could be restored to the level of wildtype cells by the re-expression of TMEM24 (Fig. $3 \mathrm{P}, \mathrm{Q})$. These results indicate that $\mathrm{Ca}^{2+}$ sequestration into the ER may be a way to compensate for excess $\mathrm{Ca}^{2+}$ increase in TMEM24 KO cells rather than being the cause of it. 

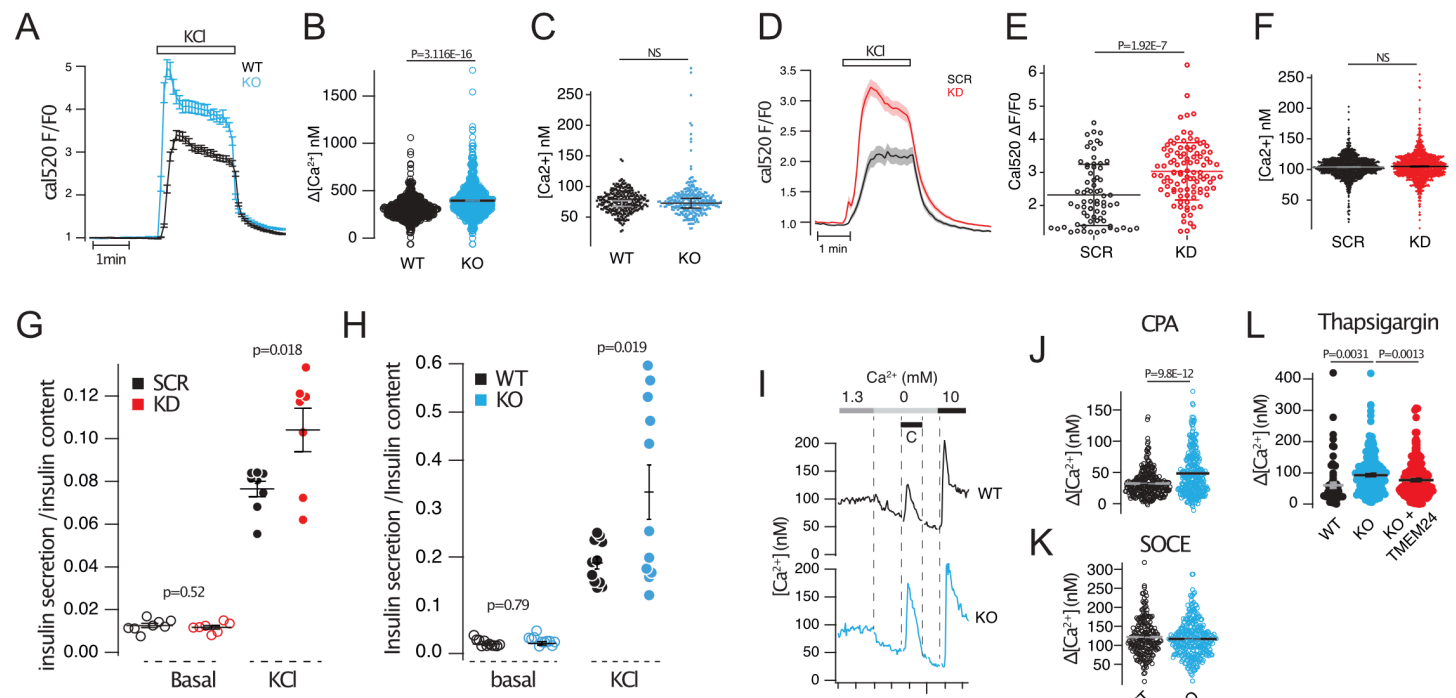

$\mathrm{H}$
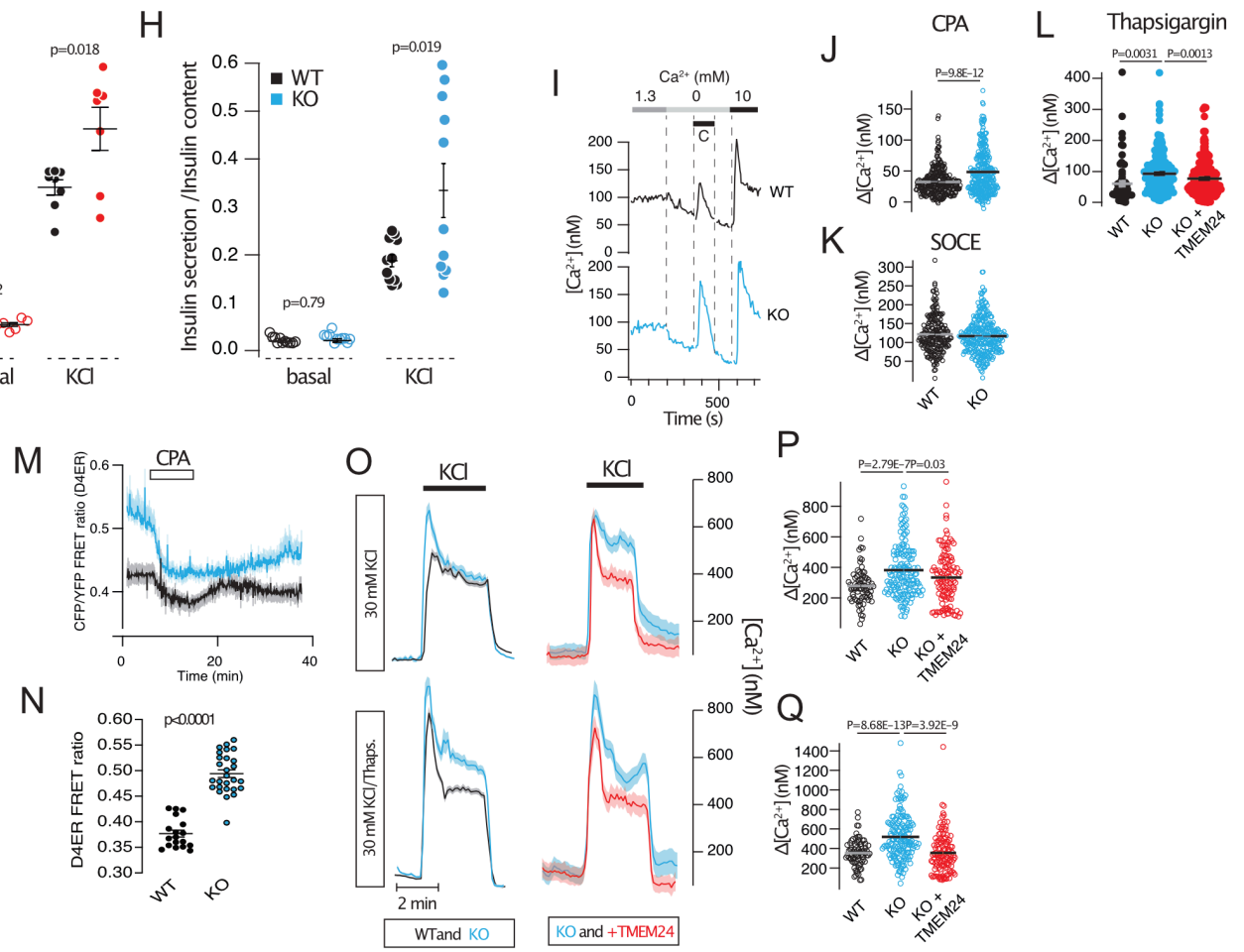

Figure 3. TMEM24 regulate ER $\mathrm{Ca}^{2+}$ homeostasis

(A) Depolarization-induced $\mathrm{Ca}^{2+}$-influx in wildtype (black) and TMEM24 KO (blue) cells. Traces show mean \pm SEM for 41 (SCR) and 54 (KD) cells from one experiment.

(B) Average cytosolic $\mathrm{Ca}^{2+}$ concentration change in response to $30 \mathrm{mM} \mathrm{KCl}$ in wildtype (black, $\mathrm{n}=298$ ) and TMEM24 KO (blue, $\mathrm{n}=397$ ) cells.

(C) Resting $\mathrm{Ca}^{2+}$ concentration in wildtype (black, $\mathrm{n}=512$ ) and TMEM24 KO (blue, $\mathrm{n}=534$ ) cells.

(D) Depolarization-induced $\mathrm{Ca}^{2+}$-influx in control (SCR, black) and TMEM24 KD (KD, red) cells. Traces show mean \pm SEM for 22 (SCR) and 19 (KD) cells from one experiment.

(E) Average Cal520 fluorescence increase in response to $30 \mathrm{mM} \mathrm{KCl}$ in control (black, $\mathrm{n}=73$ ) and TMEM24 KD (red, $\mathrm{n}=101$ ) cells.

(F) Resting $\mathrm{Ca}^{2+}$ concentration in control (black) and TMEM24 KD (red) cells.

(G) Insulin secretion in control (black) and TMEM24 KD (red) cells exposed to buffers containing basal $(5.5 \mathrm{mM})$ and depolarizing $(30 \mathrm{mM})$ concentrations of $\mathrm{KCl}(\mathrm{n}=8)$.

(H) Insulin secretion in wildtype (black) and TMEM24 KO (blue) cells exposed to buffers containing basal $(5.5 \mathrm{mM})$ and depolarizing $(30 \mathrm{mM})$ concentrations of $\mathrm{KCl}(\mathrm{n}=12)$.

(I) Representative Fura-2 recordings showing cytosolic $\mathrm{Ca} 2+$ concentration changes in wildtype (black) and TMEM24 KO (blue) cells following ER-store depletion with CPA and SOCE upon re-addition of extracellular $\mathrm{Ca} 2+$.

(J) Quantifications of the increase in cytosolic Ca2+ in wildtype (black, n=296) and TMEM24 KO cells (blue, $n=306$ ) following addition of CPA shows that TMEM24 KO cells release more Ca2 + from the ER.

(K) Quantifications of the increase in cytosolic Ca2+ in wildtype (black, $\mathrm{n}=296$ ) and TMEM24 KO cells (blue, $\mathrm{n}=306$ ) following SOCE shows that there is no difference between wildtype and TMEM24 KO cells.

(L) Quantifications of the increase in cytosolic $\mathrm{Ca} 2+$ in response to thapsigargin shows that more $\mathrm{Ca} 2+$ is released from the ER in TMEM24 KO cells (blue, n=270) compared to wildtype cells (black, $n=77$ ), and that this can be rescued by the re-expression of TMEM24 (red, n=248). 
(M) Measurements of ER Ca2+ using D4ER shows that the resting ER Ca2+ concentration is higher in TMEM24 KO cells (blue) compared to wildtype cells (black).

(N) Resting D4ER FRET ratios in WT (black; $n=18)$ and TMEM24 KO (blue; $\mathrm{n}=27)$ cells $(\mathrm{P}<0.0001)$.

(O) Average cytosolic Ca2+ concentration changes in wildtype (black), TMEM24 KO (blue) and TMEM24 $\mathrm{KO}$ with re-expression of TMEM24 (red) in response to $30 \mathrm{mM} \mathrm{KCl}$ alone (top row) or after thapsigargin addition (bottom row). Data are averages from 32-43 cells from 1 experiment per condition.

(P) Quantifications of the increase in cytosolic Ca2+ in wildtype (black, n=77) and TMEM24 KO cells (blue, $n=277$ ) following depolarization shows that there is a larger increase in TMEM24 KO cells that can be normalized by the re-expression of TMEM24 (red, $n=270$ ).

(Q) Quantifications of the increase in cytosolic Ca2+ in wildtype (black, $\mathrm{n}=77$ ) and TMEM24 KO cells (blue, $n=277$ ) following depolarization in the presence of thapsigargin shows that there is a larger increase in TMEM24 KO cells that can be normalized by the re-expression of TMEM24 (red, n=270).

\section{TMEM24 regulates mitochondrial $\mathrm{Ca}^{2+}$ handling and ATP production}

Because $\mathrm{Ca}^{2+}$ influx, extrusion and organellar sequestration all depends on ATP generated primarily via mitochondrial metabolism, we decided to complement the $\mathrm{Ca}^{2+}$ imaging with direct measurement of glucose metabolism using the Seahorse XF technique. As expected from the $\mathrm{Ca}^{2+}$ imaging data, TMEM24 knockout had little effect on the resting oxygen consumption rate (OCR) (Fig. 4A). In contrast, the accelerated OCR induced by a rise of the extracellular glucose concentration from 3 to 20 $\mathrm{mM}$ was markedly impaired in TMEM24 KO cells (Fig. 4B). However, neither the proton leak nor the maximal OCR was different between wildtype and TMEM24 KO cells, indicating that there was no gross impairment in overall mitochondrial function (Fig. 4C-F). This conclusion was supported by lack of apparent changes in mitochondrial morphology in TMEM24 KO cells as assessed by confocal microscopy of cells expressing mitochondria-targeted mApple (Tomm20-mApple) (Fig. 4G, H). Next, we measured the mitochondrial membrane potential in wildtype and TMEM24 KO cells using the fluorescent membrane potential indicator TMRM. Application of the uncoupler FCCP resulted in the immediate loss of TMRM fluorescence, which reflects depolarization of the inner mitochondrial membrane. This response was significantly smaller in TMEM24 KO cells, indicating that these cells already have partially depolarized mitochondria (Fig. 4I, J). The mitochondrial membrane potential does not only control ATP production by directly affecting the electron transport chain but also by regulating the amounts of $\mathrm{Ca}^{2+}$ that are taken up and extruded by the organelle. To determine whether TMEM24 might be involved in the regulation of mitochondrial $\mathrm{Ca}^{2+}$ we measured concentration changes in response to both CPA-mediated release of $\mathrm{Ca}^{2+}$ from the ER and depolarization-induced $\mathrm{Ca}^{2+}$ influx in wildtype and TMEM24 $\mathrm{KO}$ cell using mitochondrially targeted LAR-GECO1.2. This low-affinity sensor has a $\mathrm{K}_{\mathrm{d}}$ for $\mathrm{Ca}^{2+}$-binding of $12 \mu \mathrm{M}$, and its fluorescence is expected to increase little under normal conditions, since depolarization-induced $\mathrm{Ca}^{2+}$ influx typically results in $\mathrm{Ca}^{2+}$ concentrations in the low $\mu \mathrm{M}$ range (see e.g. Fig. 3B). Consistently, $\mathrm{KCl}$ depolarization of wildtype cells triggered a robust increase in the cytosolic $\mathrm{Ca}^{2+}$ concentration, measured with the organic dye Ca1520, but had little impact on mito-LAR-GECO1.2 fluorescence in the same cells (Fig. 4K, L). In contrast, depolarization caused a pronounced increase in mito-LAR-GECO1.2 fluorescence in TMEM24 KO cells, which was reduced to the level of wildtype cells by the re-expression of TMEM24 (Fig. 4K, L). Similar results were obtained when the $\mathrm{Ca}^{2+}$ increase was instead triggered by passive depletion from the ER through CPA-mediated SERCA inhibition (Fig. 4M, N). A possible explanation for these observations is that the resting mitochondrial $\mathrm{Ca}^{2+}$ concentration is higher in TMEM24 KO cells, thus bringing the concentration into a range better suited for detection with the low affinity sensor. Consistent with this hypothesis, we observed higher resting mito-LAR-GECO1.2 fluorescence in TMEM24 KO cells compared to wildtype cells (Fig. 4O).

We next asked how an ER-localized protein that primarily engage in lipid transport at ER-PM contact sites could impact mitochondrial function. One possibility is that TMEM24 can function at other membrane contact sites. As we show here, a large part of the PM-bound pool of TMEM24 is dynamic even under resting conditions and could therefore participate in reactions at other cellular membranes, such as those of mitochondria. To test this alternative, we expressed GFP-tagged TMEM24 together with mitochondrially localized mApple-Tomm20 in wildtype MIN6 cells. Using confocal microscopy we did not observe any mitochondrial enrichment of TMEM24 under resting conditions, but clusters appeared at mitochondria when TMEM24 dissociation from the plasma membrane was stimulated by 
bioRxiv preprint doi: https://doi.org/10.1101/2021.06.23.449694; this version posted June 24,2021 . The copyright holder for this preprint

(which was not certified by peer review) is the author/funder, who has granted bioRxiv a license to display the preprint in perpetuity. It is made available under aCC-BY-NC-ND 4.0 International license.

KCl-depolarization (Fig. 4P, Q). These clusters persisted and became even more striking when the bulk TMEM24 re-associated with the plasma membrane after terminating the depolarization (Fig. 4P, Q). These results show that TMEM24, in addition to acting at ER-PM contact sites, also may engage in reactions at ER-mitochondria contacts.

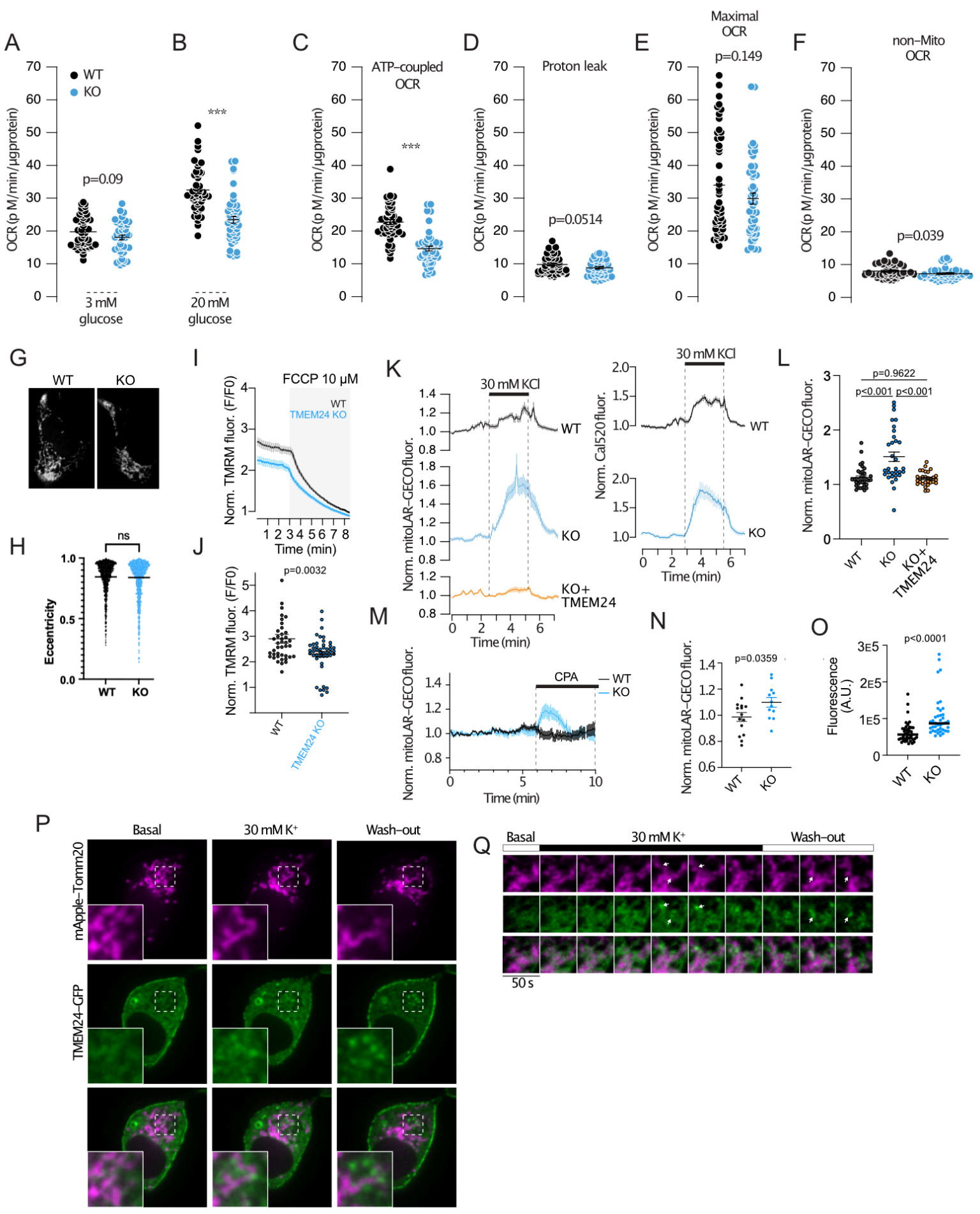

Figure 4. TMEM24 controls mitochondria $\mathrm{Ca}^{2+}$ handling and ATP production

(A) Oxygen consumption rate (OCR) in control (black) and TMEM24 KO (blue) cells at $3 \mathrm{mM}$ glucose $(\mathrm{n}=40)$.

(B) OCR in control (black) and TMEM24 KO (blue) cells at $20 \mathrm{mM}$ glucose $(\mathrm{n}=40)$. OCR is reduced in TMEM24 KO cells $(* * * \mathrm{P}<0.001)$.

(C) ATP-coupled OCR in control (black) and TMEM24 KO (blue) cells ( $\mathrm{n}=40)(* * * \mathrm{P}<0.001)$. 
(D) Proton leak in control (black) and TMEM24 KO (blue) cells ( $\mathrm{n}=40)$.

(E) Maximal OCR in control (black) and TMEM24 KO (blue) cells ( $\mathrm{n}=40)$.

(F) Non-mitochondrial OCR in control (black) and TMEM24 KO (blue) cells ( $\mathrm{n}=40)$.

(G) Confocal microscopy images of wildtype (left) and TMEM24 KO (right) cells expressing the mitochondrial marker Tom20-mApple.

(H) Measurements of the eccentricity of identified mitochondria in wildtype (black) and TMEM24 KO (blue) cells ( $\mathrm{n}=918$ mitochondria from 50 cells for WT and $\mathrm{n}=1037$ mitochondria from 55 cells for KO, $\mathrm{P}=0.3965)$.

(I) Epifluorescence microscopy recordings of TMRM fluorescence from wildtype (black) and TMEM24 $\mathrm{KO}$ (blue) cells in response to $10 \mu \mathrm{M}$ FCCP which causes dissipation of the inner mitochondrial membrane potential. Data presented are means \pm SEM for 40 (WT) and $46(\mathrm{KO})$ cells from 3 experiments.

(J) Resting TMRM fluorescence values in wildtype and TMEM24 KO cells after normalization to the fluorescence intensity in the presence of $10 \mu \mathrm{M} \mathrm{FCCP}(\mathrm{n}=40-46$ cells; $\mathrm{P}=0.0032)$.

(K) Epifluorescence microscopy recordings of mito-LAR-GECO (left column) and Cal520 (right column) fluorescence from wildtype cells (black; $n=36$ cells), TMEM24 KO cells (blue; $n=32$ cells) and TMEM24 KO cells with re-expression of TMEM24 (yellow; $n=32$ cells) (averages $\pm \mathrm{SEM}$; $\mathrm{P}<0.0001$ for KO to WT and $\mathrm{P}=0.9622$ for WT to rescue, One-way ANOVA).

(L) Mito-LAR-GECO fluorescence change in response to $30 \mathrm{mM} \mathrm{KCl}$ in wildtype cells (black; $\mathrm{n}=40$ cells), TMEM24 KO cells (blue; $n=42$ cells) and TMEM24 KO cells with re-expression of TMEM24 (yellow; $\mathrm{n}=29$ cells).

(M) Epifluorescence microscopy recordings of mito-LAR-GECO fluorescence from wildtype (black; n=15) and TMEM24 KO (blue; $n=12$ ) cells (averages \pm SEM).

(N) Mito-LAR-GECO fluorescence change in response to $100 \mu \mathrm{M}$ CPA in wildtype (black) and TMEM24 $\mathrm{KO}$ (blue) cells $(\mathrm{P}=0.0359)$.

(O) Resting mito-LAR-GECO fluorescence intensity in wildtype (black; $n=50$ cells) and TMEM24 KO (blue; $\mathrm{n}=43$ cells) cells $(\mathrm{P}<0.0001)$.

(P) Confocal microscopy images of a MIN6 cells expressing mApple Tomm20 (magenta) and TMEM24GFP (green) under resting conditions, during stimulation with $30 \mathrm{mM} \mathrm{KCl}$ and following washout of the depolarizing stimuli. Boxed areas are magnified in the lower left corner and shows the appearance of TMEM24-GFP-positive puncta at mitochondria.

(Q) Time-course of KCl-induced TMEM24 dissociation from the plasma membrane and association with mitochondria. Bars onto indicate addition and removal of $\mathrm{KCl}$. Time interval between images is $50 \mathrm{~s}$.

\section{DISCUSSION}

Previous work has established the ER-localized lipid-transport protein TMEM24 as an important regulator of insulin secretion from pancreatic $\beta$-cells (Lees et al., 2017; Pottekat et al., 2013). Transient reduction of TMEM24 expression or knockout of the TMEM24 gene have been found to impair insulin secretion from clonal rat and mouse $\beta$-cells. The underlying mechanism has been proposed to involve reduced $\mathrm{Ca}^{2+}$-independent recruitment of insulin granules to the plasma membrane (Pottekat et al., 2013) or disturbed regulation of voltage-dependent $\mathrm{Ca}^{2+}$ influx through alterations in the plasma membrane lipid composition (Lees et al., 2017). In this work, we further explored the mechanisms underlying TMEM24-dependent regulation of insulin secretion. In contrast to previous studies, we found that reduced expression of TMEM24 has little impact on voltagedependent $\mathrm{Ca}^{2+}$ influx and insulin secretion from $\beta$-cells. Instead, we identified TMEM24 as an important regulator of $\mathrm{Ca}^{2+}$ homeostasis at both the endoplasmic reticulum and the mitochondria, and show that this protein regulates mitochondrial ATP production.

TMEM24 is anchored to the endoplasmic reticulum through an N-terminal transmembrane domain and contains, in sequence, a lipid-binding SMP-domain, a C2-domain and a polybasic Cterminus. It is highly expressed in neuronal and endocrine tissue, including the pancreatic islets of Langerhans, where it is involved in tethering the ER to the plasma membrane (Lees et al., 2017; Sun et al., 2019). Its localization to the plasma membrane depends on electrostatic interactions between the $\mathrm{C}$-terminus and cationic lipids in the plasma membrane, and neutralization of charged amino acids in TMEM24 by PKC-dependent phosphorylation results in TMEM24 dissociation. Using both intact and permeabilized cells, we found that the $\mathrm{Ca}^{2+}$-dependent dissociation of TMEM24 from the plasma membrane can be triggered already at nanomolar elevations of cytosolic $\mathrm{Ca}^{2+}$ by intracellular release 
or extracellular influx. Interestingly, we found that TMEM24 is already partially displaced from the plasma membrane under resting $\mathrm{Ca}^{2+}$ concentrations, perhaps due to constitutive PKC activity. This is consistent with findings from neuron-like cells where endogenous TMEM24 was found both at the plasma membrane and in the bulk ER under resting conditions (Sun et al., 2019). Such observations would support the hypothesis that TMEM24 acts at additional cellular locations, perhaps driven by interactions with acidic lipids in the membranes of organelles known to form contacts with the ER (Cohen et al., 2018; Eden et al., 2010). By locally photobleaching a small region of the plasma membrane in cells expressing TMEM24-GFP, we could also estimate the mobility of TMEM24 at ERPM junctions. We found that TMEM24 weakly interacts with the plasma membrane, and that a large fraction was highly dynamic under resting conditions, which is in sharp contrast to ExtendedSynaptotagmin-2, another SMP-domain-containing protein constitutively localized to ER-PM contact sites (Xie et al., 2019). This observation is also consistent with TMEM24 executing functions at other cellular locations than the plasma membrane.

In contrast to previous studies (Lees et al., 2017; Pottekat et al., 2013), we did not find support for a requirement of TMEM24 for normal insulin secretion. Both transient knockdown of TMEM24 using siRNA and CRISPR/Cas9-mediated knockout of TMEM24 had little effect on either glucose- or depolarization-induced $\mathrm{Ca}^{2+}$ influx and insulin secretion. If anything, cells with reduced expression performed slightly better than control cells. One previous study, in which TMEM24 expression was stably reduced by shRNA, showed impaired glucose-stimulated insulin secretion from both clonal rat INS1 and mouse MIN6 $\beta$-cells. However, the $\mathrm{Ca}^{2+}$ responses in these cells were normal, and secretion in response to direct depolarization was also unaffected by TMEM24 knockdown (Pottekat et al., 2013). CRISPR/Cas9-mediated knockout of TMEM24 in INS1 cells resulted in complete inhibition of both glucose-induced $\mathrm{Ca}^{2+}$ increases and insulin secretion, which was restored by re-expression of full-length TMEM24 (Lees et al., 2017). Although INS1 cells secrete insulin in response to glucose, the mechanism is likely different from that of primary $\beta$-cells in that it not only depends on $\mathrm{K}_{\text {ATP- }}$ channel closure (Herbst et al., 2002) and voltage-dependent $\mathrm{Ca}^{2+}$ influx (Dorff et al., 2002). Insulin secretion may instead be triggered by $\mathrm{Ca}^{2+}$ released from intracellular stores, since addition of the ER $\mathrm{Ca}^{2+}$ ATPase (SERCA) inhibitor thapsigargin causes $\mathrm{Ca}^{2+}$ oscillations in these cells (Herbst et al., 2002). We found that TMEM 24 knockout cells have increased $\mathrm{Ca}^{2+}$ accumulation in the ER, observed by both measurements of cytosolic $\mathrm{Ca}^{2+}$ following ER-store depletion and by direct measurements of $\mathrm{ER} \mathrm{Ca}^{2+}$. It is not clear how TMEM24 contributes to ER $\mathrm{Ca}^{2+}$ homeostasis. The major route of $\mathrm{Ca}^{2+}$ uptake into the ER of $\beta$-cells is the SERCA (Roe et al., 1994) but we did not find any evidence for increased SERCA activity in TMEM $24 \mathrm{KO}$ cells. If anything, the activity was slightly reduced, as indicated by the lack of an initial $\mathrm{Ca}^{2+}$ lowering effect of glucose in TMEM $24 \mathrm{KO}$ cells, although this might also reflect the impaired ATP production or the steeper concentration gradient in these cells. There is a continuous leakage of $\mathrm{Ca}^{2+}$ from the ER, which results in rapid loss of $\mathrm{Ca}^{2+}$ upon SERCA inhibition, but the mechanism behind this leak is not clear. Numerous mediators of ER $\mathrm{Ca}^{2+}$ leak have been identified, including presenilin-1/2 and TMCO1 (Tu et al., 2006; Q. C. Wang et al., 2016). Reduced ER Ca ${ }^{2+}$ leak could explain the increased accumulation of $\mathrm{Ca}^{2+}$ in the ER of TMEM24 KO cells. Interestingly, loss of both presenilin-1 and TMCO1, like TMEM24, results in ER $\mathrm{Ca}^{2+}$ overload and in impaired mitochondria function (Tu et al., 2006; Q. C. Wang et al., 2016; X. Wang et al., 2019). Although TMEM 24 unlikely functions as a $\mathrm{Ca}^{2+}$ channel, it may modulate other release mechanisms either through direct interactions or modulation of the lipid environment. Because of its dynamic nature, TMEM24 may provide means to acutely regulate $\mathrm{ER} \mathrm{Ca}^{2+}$ permeability in response to increases in cytosolic $\mathrm{Ca}^{2+}$ or plasma membrane DAG concentrations.

In addition to its effect on ER $\mathrm{Ca}^{2+}$, we found that TMEM24 is involved in the regulation of mitochondria function. Increases in the cytosolic $\mathrm{Ca}^{2+}$ concentration causes the dissociation of TMEM24 from the plasma membrane and is followed by accumulation of TMEM24 at mitochondria. This is similar to other ER-localized lipid transport proteins, such as ORP5/8 and Vps13A/C, which has been shown to bind more than one organelle membrane (Galmes et al., 2016; Kumar et al., 2018). We also showed that the basal mitochondrial $\mathrm{Ca}^{2+}$ concentration is elevated in TMEM24 KO cells. However, these mitochondria are still able take up and release $\mathrm{Ca}^{2+}$ in response to changes in cytosolic $\mathrm{Ca}^{2+}$, arguing against defects in the major uptake and extrusion pathways. Consistent with the 
accumulation of $\mathrm{Ca}^{2+}$, we also found that the inner mitochondrial membrane was depolarized compared to mitochondria of wildtype cells and that the glucose-induced ATP production was impaired. It is currently not clear if it is the change in mitochondrial membrane potential that facilitates $\mathrm{Ca}^{2+}$ uptake via the mitochondrial calcium uniporter (MCU) complex or if the $\mathrm{Ca}^{2+}$ overload instead drives the depolarization. Irrespective of cause, it is likely that TMEM24 exert its effect on mitochondria at ER-mitochondria contact sites. These sites for $\mathrm{Ca}^{2+}$ and lipid exchange are important for controlling mitochondria $\mathrm{Ca}^{2+}$ levels, ATP production and mitochondria morphology in $\beta$-cells (Rieusset, 2018). It is possible that the increased $\mathrm{Ca}^{2+}$ concentration in the ER of TMEM24 KO cells causes a concomitant rise of $\mathrm{Ca}^{2+}$ in the mitochondria as these contact sites concentrate many of the key components of organellar $\mathrm{Ca}^{2+}$ homeostasis, including the $\mathrm{MCU}$, the voltage-dependent anion channel (VDAC), SERCA, Presenilin-1 and IP3 receptors (Area-Gomez et al., 2009; Vecellio Reane et al., 2020). The MCU has low affinity for $\mathrm{Ca}^{2+}$ and is kept inactive under resting cytosolic $\mathrm{Ca}^{2+}$ concentrations (Marchi \& Pinton, 2014). However, MCU is still important for maintaining basal energy production, likely via sensing $\mathrm{Ca}^{2+}$ microdomains formed by $\mathrm{Ca}^{2+}$ release from the ER at ERmitochondria contacts (Rossi et al., 2019). Another intriguing possibility is that TMEM24 modulates the lipid composition of the mitochondria membranes, and that lack of this transport alters mitochondria function. TMEM24 has a strong preference for phosphatidylinositol, and the importance of this lipid for mitochondria function has been known since the 1960ies (Vignais et al., 1963). More recently, it has been shown that that the outer mitochondrial membrane is indeed rich in phosphatidylinositol (Zewe et al., 2020), and that phosphorylated derivatives of this lipid are required for mitochondrial function (Nagashima et al., 2020; Rosivatz \& Woscholski, 2011). However, it remains to discover how phosphatidylinositol is delivered to the mitochondria. One possibility is that TMEM24 contributes to this transport and couples it to changes in $\mathrm{Ca}^{2+}$ concentration and energy demand. Interestingly, one study found that depletion or masking of $\mathrm{PI}(4,5) \mathrm{P}_{2}$ on the mitochondria surface caused mitochondrial fragmentation, which could be prevented by PKC activation that would also trigger TMEM24 dissociation from the plasma membrane to enable interactions with the mitochondria (Rosivatz \& Woscholski, 2011). $\mathrm{A} \mathrm{Ca}^{2+}$-dependent feedback system to control mitochondria function may be particularly important in the $\beta$-cells, where mitochondrial metabolism is tightly coupled to $\mathrm{Ca}^{2+}$ influx in order to adjust insulin secretion and maintain blood glucose homeostasis.

\section{AUTHOR CONTRIBUTION}

BX and SP performed all experiments and analyzed all data, except for the metabolic measurements presented in Fig. 4, which were done by CJ. BX and OI-H wrote the manuscript with input from SP, $\mathrm{PG}, \mathrm{CJ}$ and PB.

\section{ACKNOWLEDGEMENT}

We are grateful to Mrs. Antje Thonig for excellent help with molecular biology work and insulin secretion measurements and to Prof. Erik Gylfe and all members of the OI-H lab for input on the work. This study was funded by grants from The Novo-Nordisk Foundation, The Swedish Research Council, Åke Wibergs Stiftelse, Diabetesfonden and Exodiab (all to OI-H). P.G. is Research Director of the Fonds National de la Recherche Scientifique (Brussels).

\section{REFERENCES}

Area-Gomez, E., De Groof, A. J. C., Boldogh, I., Bird, T. D., Gibson, G. E., Koehler, C. M., Yu, W. H., Duff, K. E., Yaffe, M. P., Pon, L. A., \& Schon, E. A. (2009). Presenilins are enriched in endoplasmic reticulum membranes associated with mitochondria. American Journal of Pathology. https://doi.org/10.2353/ajpath.2009.090219

Balla, T. (2018). Ca2+ and lipid signals hold hands at endoplasmic reticulum-plasma membrane 
contact sites. Journal of Physiology. https://doi.org/10.1113/JP274957

Bian, X., Saheki, Y., \& De Camilli, P. (2018). Ca 2+ releases E-Syt1 autoinhibition to couple ER plasma membrane tethering with lipid transport . The EMBO Journal. https://doi.org/10.15252/embj.201797359

Carpenter, A. E., Jones, T. R., Lamprecht, M. R., Clarke, C., Kang, I. H., Friman, O., Guertin, D. A., Chang, J. H., Lindquist, R. A., Moffat, J., Golland, P., \& Sabatini, D. M. (2006). CellProfiler: Image analysis software for identifying and quantifying cell phenotypes. Genome Biology. https://doi.org/10.1186/gb-2006-7-10-r100

Chen, L., Koh, D. S., \& Hille, B. (2003). Dynamics of calcium clearance in mouse pancreatic $\beta$-cells. Diabetes. https://doi.org/10.2337/diabetes.52.7.1723

Chung, W. Y., Jha, A., Ahuja, M., \& Muallem, S. (2017). Ca2+ influx at the ER/PM junctions. Cell Calcium. https://doi.org/10.1016/j.ceca.2017.02.009

Cohen, S., Valm, A. M., \& Lippincott-Schwartz, J. (2018). Interacting organelles. In Current Opinion in Cell Biology. https://doi.org/10.1016/j.ceb.2018.06.003

Dorff, G., Grapengiesser, E., \& Hellman, B. (2002). Insulin-secreting INS-1 cells generate a novel type of poorly synchronized $\mathrm{Ca} 2+$ transients. Biochemical and Biophysical Research Communications. https://doi.org/10.1016/S0006-291X(02)00311-X

Eden, E. R., White, I. J., Tsapara, A., \& Futter, C. E. (2010). Membrane contacts between endosomes and ER provide sites for PTP1B-epidermal growth factor receptor interaction. Nature Cell Biology. https://doi.org/10.1038/ncb2026

Galmes, R., Houcine, A., Vliet, A. R., Agostinis, P., Jackson, C. L., \& Giordano, F. (2016). ORP5/ORP8 localize to endoplasmic reticulum-mitochondria contacts and are involved in mitochondrial function. EMBO Reports. https://doi.org/10.15252/embr.201541108

Giordano, F., Saheki, Y., Idevall-Hagren, O., Colombo, S. F., Pirruccello, M., Milosevic, I., Gracheva, E. O., Bagriantsev, S. N., Borgese, N., \& De Camilli, P. (2013). XPI(4,5)P2-Dependent and $\mathrm{Ca} 2+-$ Regulated ER-PM interactions mediated by the extended synaptotagmins. Cell. https://doi.org/10.1016/j.cell.2013.05.026

Hammond, G. R. V., Machner, M. P., \& Balla, T. (2014). A novel probe for phosphatidylinositol 4phosphate reveals multiple pools beyond the Golgi. Journal of Cell Biology. https://doi.org/10.1083/jcb.201312072

Herbst, M., Sasse, P., Greger, R., Yu, H., Hescheler, J., \& Ullrich, S. (2002). Membrane potential dependent modulations of calcium oscillations in insulin-secreting INS-1 cells. Cell Calcium. https://doi.org/10.1054/ceca.2001.0266

Idevall-Hagren, O., Barg, S., Gylfe, E., \& Tengholm, A. (2010). cAMP mediators of pulsatile insulin secretion from glucose-stimulated single $\beta$-cells. Journal of Biological Chemistry. https://doi.org/10.1074/jbc.M109.095992

Idevall-Hagren, O., Jakobsson, I., Xu, Y., \& Tengholm, A. (2013). Spatial control of Epac2 activity by cAMP and $\mathrm{Ca} 2+-$ mediated activation of ras in pancreatic $\beta$ cells. Science Signaling. https://doi.org/10.1126/scisignal.2003932

Idevall-Hagren, O., Lü, A., Xie, B., \& De Camilli, P. (2015). Triggered Ca 2+ influx is required for extended synaptotagmin 1-induced ER -plasma membrane tethering . The EMBO Journal. https://doi.org/10.15252/embj.201591565

Johnson, B., Leek, A. N., Solé, L., Maverick, E. E., Levine, T. P., \& Tamkun, M. M. (2018). Kv2 potassium channels form endoplasmic reticulum/plasma membrane junctions via interaction with VAPA and VAPB. Proceedings of the National Academy of Sciences of the United States of America. https://doi.org/10.1073/pnas.1805757115

Kumar, N., Leonzino, M., Hancock-Cerutti, W., Horenkamp, F. A., Li, P. Q., Lees, J. A., Wheeler, H., Reinisch, K. M., \& De Camilli, P. (2018). VPS13A and VPS13C are lipid transport proteins differentially localized at ER contact sites. Journal of Cell Biology. https://doi.org/10.1083/JCB.201807019

Lees, J. A., Messa, M., Sun, E. W., Wheeler, H., Torta, F., Wenk, M. R., De Camilli, P., \& Reinisch, K. M. (2017). Lipid transport by TMEM24 at ER-plasma membrane contacts regulates pulsatile insulin secretion. Science. https://doi.org/10.1126/science.aah6171

Marchi, S., \& Pinton, P. (2014). The mitochondrial calcium uniporter complex: Molecular components, structure and physiopathological implications. In Journal of Physiology. 
https://doi.org/10.1113/jphysiol.2013.268235

Miyazaki, J. I., Araki, K., Yamato, E., Ikegami, H., Asano, T., Shibasaki, Y., Oka, Y., Yamamura, K. I., \& Miyazaki, J. I. (1990). Establishment of a pancreatic $\beta$ cell line that retains glucoseinducible insulin secretion: Special reference to expression of glucose transporter isoforms. Endocrinology. https://doi.org/10.1210/endo-127-1-126

Nagashima, S., Tábara, L. C., Tilokani, L., Paupe, V., Anand, H., Pogson, J. H., Zunino, R., McBride, H. M., \& Prudent, J. (2020). Golgi-derived PI(4)P-containing vesicles drive late steps of mitochondrial division. Science. https://doi.org/10.1126/science.aax6089

Pottekat, A., Becker, S., Spencer, K. R., Yates, J. R., Manning, G., Itkin-Ansari, P., \& Balch, W. E. (2013). Insulin biosynthetic interaction network component, TMEM24, facilitates insulin reserve pool release. Cell Reports. https://doi.org/10.1016/j.celrep.2013.07.050

Ravier, M. A., Daro, D., Roma, L. P., Jonas, J. C., Cheng-Xue, R., Schuit, F. C., \& Gilon, P. (2011). Mechanisms of control of the free $\mathrm{Ca} 2+$ concentration in the endoplasmic reticulum of mouse pancreatic $\beta$-cells: Interplay with cell metabolism and $[\mathrm{Ca} 2+] \mathrm{c}$ and role of SERCA2b and SERCA3. Diabetes. https://doi.org/10.2337/db10-1543

Rieusset, J. (2018). The role of endoplasmic reticulum-mitochondria contact sites in the control of glucose homeostasis: An update. Cell Death and Disease. https://doi.org/10.1038/s41419-0180416-1

Roe, M. W., Mertz, R. J., Lancaster, M. E., Worley, J. F., \& Dukes, I. D. (1994). Thapsigargin inhibits the glucose-induced decrease of intracellular Ca2+in mouse islets of Langerhans. American Journal of Physiology - Endocrinology and Metabolism. https://doi.org/10.1152/ajpendo.1994.266.6.e852

Rorsman, P., \& Ashcroft, F. M. (2018). Pancreatic $\beta$-cell electrical activity and insulin secretion: Of mice and men. Physiological Reviews. https://doi.org/10.1152/physrev.00008.2017

Rosivatz, E., \& Woscholski, R. (2011). Removal or masking of phosphatidylinositol(4,5)bisphosphate from the outer mitochondrial membrane causes mitochondrial fragmentation. Cellular Signalling. https://doi.org/10.1016/j.cellsig.2010.10.025

Rossi, A., Pizzo, P., \& Filadi, R. (2019). Calcium, mitochondria and cell metabolism: A functional triangle in bioenergetics. In Biochimica et Biophysica Acta - Molecular Cell Research. https://doi.org/10.1016/j.bbamcr.2018.10.016

Saheki, Y., \& De Camilli, P. (2017). Endoplasmic reticulum-plasma membrane contact sites. In Annual Review of Biochemistry. https://doi.org/10.1146/annurev-biochem-061516-044932

Schindelin, J., Arganda-Carreras, I., Frise, E., Kaynig, V., Longair, M., Pietzsch, T., Preibisch, S., Rueden, C., Saalfeld, S., Schmid, B., Tinevez, J. Y., White, D. J., Hartenstein, V., Eliceiri, K., Tomancak, P., \& Cardona, A. (2012). Fiji: An open-source platform for biological-image analysis. In Nature Methods. https://doi.org/10.1038/nmeth.2019

Suh, B. C., Leal, K., \& Hille, B. (2010). Modulation of high-voltage activated Ca2+ channels by membrane phosphatidylinositol 4,5-bisphosphate. Neuron. https://doi.org/10.1016/j.neuron.2010.07.001

Sun, E. W., Guillén-Samander, A., Bian, X., Wu, Y., Cai, Y., Messa, M., \& De Camilli, P. (2019). Lipid transporter TMEM24/C2CD2L is a Ca 2+-regulated component of ER-plasma membrane contacts in mammalian neurons. Proceedings of the National Academy of Sciences of the United States of America. https://doi.org/10.1073/pnas.1820156116

Tu, H., Nelson, O., Bezprozvanny, A., Wang, Z., Lee, S. F., Hao, Y. H., Serneels, L., De Strooper, B., Yu, G., \& Bezprozvanny, I. (2006). Presenilins Form ER Ca2+ Leak Channels, a Function Disrupted by Familial Alzheimer's Disease-Linked Mutations. Cell. https://doi.org/10.1016/j.cell.2006.06.059

Vecellio Reane, D., Rizzuto, R., \& Raffaello, A. (2020). The ER-mitochondria tether at the hub of Ca2+ signaling. In Current Opinion in Physiology. https://doi.org/10.1016/j.cophys.2020.08.013

Vignais, P. M., Vignais, P. V., \& Lehninger, A. L. (1963). Restoration of ATP-induced contraction of "aged" mitochondria by phosphatidyl inositol. Biochemical and Biophysical Research Communications. https://doi.org/10.1016/0006-291X(63)90563-1

Wang, Q. C., Zheng, Q., Tan, H., Zhang, B., Li, X., Yang, Y., Yu, J., Liu, Y., Chai, H., Wang, X., Sun, Z., Wang, J. Q., Zhu, S., Wang, F., Yang, M., Guo, C., Wang, H., Zheng, Q., Li, Y., ... Tang, T. S. (2016). TMCO1 is an ER Ca2+ load-activated Ca2+ channel. Cell. 
https://doi.org/10.1016/j.cell.2016.04.051

Wang, X., Wang, Q. C., Sun, Z., Li, T., Yang, K., An, C., Guo, C., \& Tang, T. S. (2019). ER stress mediated degradation of diacylglycerol acyltransferase impairs mitochondrial functions in TMCO1 deficient cells. Biochemical and Biophysical Research Communications. https://doi.org/10.1016/j.bbrc.2019.03.115

Wu, J., Prole, D. L., Shen, Y., Lin, Z., Gnanasekaran, A., Liu, Y., Chen, L., Zhou, H., Chen, S. R. W., Usachev, Y. M., Taylor, C. W., \& Campbell, R. E. (2014). Red fluorescent genetically encoded $\mathrm{Ca} 2+$ indicators for use in mitochondria and endoplasmic reticulum. Biochemical Journal. https://doi.org/10.1042/BJ20140931

Wuttke, A. (2015). Lipid signalling dynamics at the $\beta$-cell plasma membrane. Basic and Clinical Pharmacology and Toxicology. https://doi.org/10.1111/bcpt.12369

Wuttke, A., Idevall-Hagren, O., \& Tengholm, A. (2013). P2Y1 receptor-dependent diacylglycerol signaling microdomains in $\beta$ cells promote insulin secretion. FASEB Journal. https://doi.org/10.1096/fj.12-221499

Wuttke, A., Yu, Q., \& Tengholm, A. (2016). Autocrine signaling underlies fast repetitive plasma membrane translocation of conventional and novel protein kinase $\mathrm{C}$ isoforms in $\beta$ cells. Journal of Biological Chemistry. https://doi.org/10.1074/jbc.M115.698456

Xie, B., Nguyen, P. M., Guček, A., Thonig, A., Barg, S., \& Idevall-Hagren, O. (2016). Plasma Membrane Phosphatidylinositol 4,5-Bisphosphate Regulates Ca2+-Influx and Insulin Secretion from Pancreatic $\beta$ Cells. Cell Chemical Biology. https://doi.org/10.1016/j.chembiol.2016.06.009

Xie, B., Nguyen, P. M., \& Idevall-Hagren, O. (2019). Feedback regulation of insulin secretion by extended synaptotagmin-1. FASEB Journal. https://doi.org/10.1096/fj.201801878R

Zewe, J. P., Miller, A. M., Sangappa, S., Wills, R. C., Goulden, B. D., \& Hammond, G. R. V. (2020). Probing the subcellular distribution of phosphatidylinositol reveals a surprising lack at the plasma membrane. Journal of Cell Biology. https://doi.org/10.1083/JCB.201906127

Zhao, Y., Araki, S., Wu, J., Teramoto, T., Chang, Y. F., Nakano, M., Abdelfattah, A. S., Fujiwara, M., Ishihara, T., Nagai, T., \& Campbell, R. E. (2011). An expanded palette of genetically encoded Ca2+ indicators. Science. https://doi.org/10.1126/science.1208592 


\section{SUPPLEMENTARY FIGURES}

A

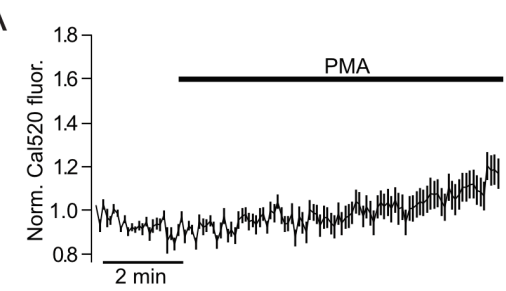

B
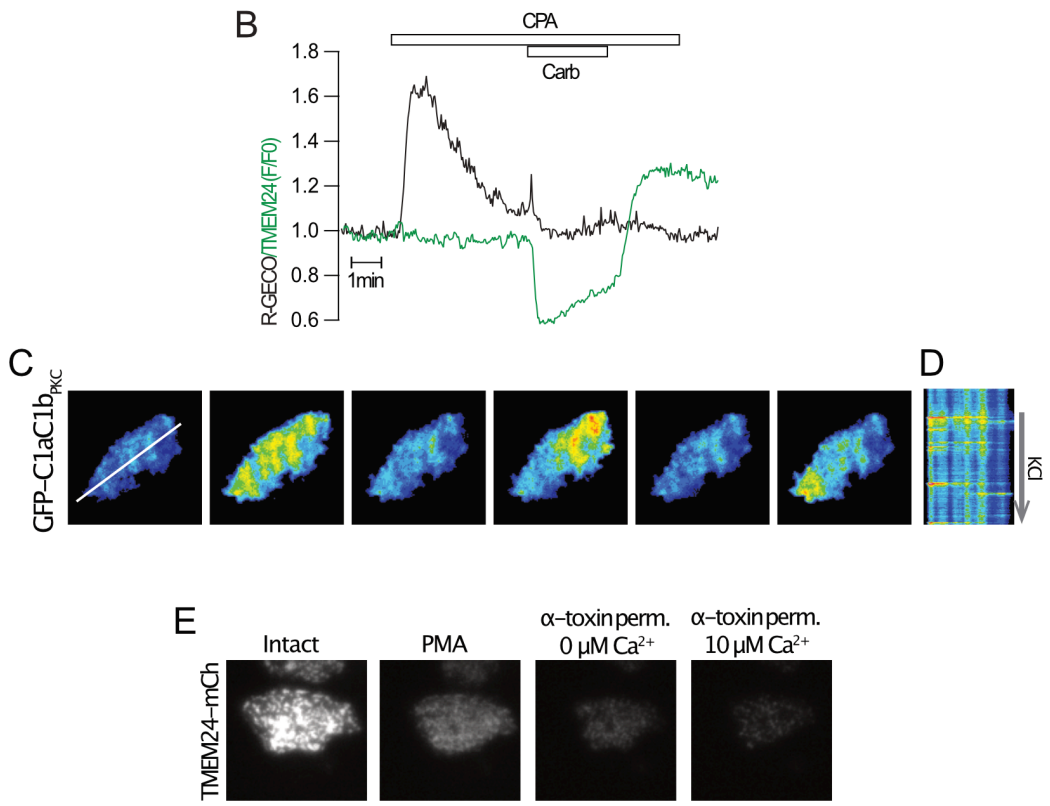

$\alpha$-toxinperm. $\alpha$-toxinperm
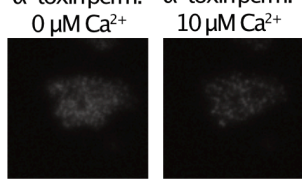

\section{Supplementary Figure 1.}

(A) Recordings of cytosolic $\mathrm{Ca}^{2+}$ in MIN6 cells loaded with the fluorescent $\mathrm{Ca}^{2+}$ indicator Cal520 following addition of $1 \mu \mathrm{M}$ PMA. Data presented are means \pm SEM for 26 cells.

(B) TIRF microscopy recording of R-GECO (black; $\mathrm{Ca}^{2+}$ ) and GFP-TMEM24 (green) fluorescence from a MIN6 cells exposed to $100 \mu \mathrm{M}$ CPA and $10 \mu \mathrm{M}$ carbachol.

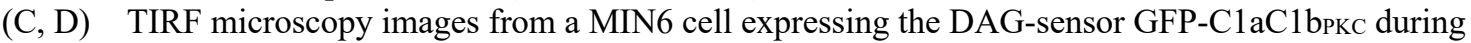
depolarization with $30 \mathrm{mM} \mathrm{KCl}$. Notice the irregular formation of DAG at the plasma membrane, apparent as transient, localized fluorescence increase events in the kymograph in D.

(E) TIRF microscopy images GFP-TMEM24 fluorescence from a MIN6 cell that is first exposed to $1 \mu \mathrm{M}$ of the DAG analogue PMA, followed by permeabilization in an intracellular-like buffer and exposure to the indicated $\mathrm{Ca}^{2+}$ concentrations. Notice that most of the plasma-membrane-associated GFP-TMEM24 fluorescence is lost following addition of PMA. 
bioRxiv preprint doi: https://doi.org/10.1101/2021.06.23.449694; this version posted June 24, 2021. The copyright holder for this preprint (which was not certified by peer review) is the author/funder, who has granted bioRxiv a license to display the preprint in perpetuity. It is made available under aCC-BY-NC-ND 4.0 International license. 